\title{
Label-free Method for Classification of T cell Activation
}

Alex J. Walsh ${ }^{1, *}$, Katie Mueller ${ }^{2,3}$, Isabel Jones ${ }^{1}$, Christine M. Walsh ${ }^{1,4}$, Nicole Piscopo ${ }^{2,3}$, Natalie N. Niemi ${ }^{1,5}$, David J. Pagliarini ${ }^{1,5}$, Krishanu Saha ${ }^{2,3}$ and Melissa C. Skala ${ }^{1,3,}$

${ }^{1}$ Morgridge Institute for Research, Madison, Wisconsin

${ }^{2}$ Wisconsin Institute for Discovery, University of Wisconsin-Madison, Madison, Wisconsin

${ }^{3}$ Department of Biomedical Engineering, University of Wisconsin-Madison, Madison, Wisconsin

${ }^{4}$ Department of Sociology, State University of New York, Albany, New York

${ }^{5}$ Department of Biochemistry, University of Wisconsin-Madison, Madison, Wisconsin

*Corresponding Authors

\begin{abstract}
T cells have a range of cytotoxic and immune-modulating functions, depending on activation state and subtype. However, current methods to assess $\mathrm{T}$ cell function use exogenous labels that often require cell permeabilization, which is limiting for time-course studies of $\mathrm{T}$ cell activation and non-destructive quality control of immunotherapies. Label-free optical imaging is an attractive solution. Here, we use autofluorescence imaging of $\mathrm{NAD}(\mathrm{P}) \mathrm{H}$ and $\mathrm{FAD}$, co-enzymes of metabolism, to quantify optical imaging endpoints in quiescent and activated T cells. Machine learning classification models were developed for label-free, non-destructive determination of $\mathrm{T}$ cell activation state. $\mathrm{T}$ cells were isolated from the peripheral blood of human donors, and a subset were activated with a tetrameric antibody against CD2/CD3/CD28 surface ligands. $\mathrm{NAD}(\mathrm{P}) \mathrm{H}$ and FAD autofluorescence intensity and lifetime of the $\mathrm{T}$ cells were imaged using a multiphoton fluorescence lifetime microscope. Significant differences in autofluorescence imaging endpoints were observed between quiescent and activated T cells. Feature selection methods revealed that the contribution of the short $\mathrm{NAD}(\mathrm{P}) \mathrm{H}$ lifetime $\left(\alpha_{1}\right)$ is the most important feature for classification of activation state, across multiple donors and T cell subsets. Logistic regression models achieved 97-99\% accuracy for classification of $\mathrm{T}$ cell activation from the autofluorescence imaging endpoints. Additionally, autofluorescence imaging revealed $\mathrm{NAD}(\mathrm{P}) \mathrm{H}$ and FAD autofluorescence differences between $\mathrm{CD} 3^{+} \mathrm{CD} 8^{+}$ and $\mathrm{CD} 3^{+} \mathrm{CD} 4^{+} \mathrm{T}$ cells, and random forest models of the autofluorescence imaging endpoints achieved $97+\%$ accuracy for four-group classification of quiescent and activated CD3 ${ }^{+} \mathrm{CD} 8^{+}$and $\mathrm{CD} 3^{+} \mathrm{CD} 4^{+} \mathrm{T}$
\end{abstract}


cells. Altogether these results indicate that autofluorescence imaging of $\mathrm{NAD}(\mathrm{P}) \mathrm{H}$ and FAD is a powerful method for label-free, non-destructive determination of $\mathrm{T}$ cell activation and subtype, which could have important applications for the treatment of cancer, autoimmune, infectious, and other diseases.

\section{Introduction}

T cells are an important component of the adaptive immune response and have diverse cytotoxic and immunemodulating, or "helper" activities, upon activation. The two main $\mathrm{T}$ cell subtypes are $\mathrm{CD} 3^{+} \mathrm{CD} 8^{+} \mathrm{T}$ cells that engage in cell-mediated cytotoxicity and release toxic cytokines, including interferon gamma (IFN- $\gamma$ ) and tumor necrosis factor alpha $(\mathrm{TNF}-\alpha)$, and $\mathrm{CD} 3^{+} \mathrm{CD} 4^{+} \mathrm{T}$ cells that can be further divided into additional subtypes with differing pro- and anti- inflammatory functions due to chemokine and cytokine production[1, 2]. $\mathrm{T}$ cells are a promising target for immunotherapies because of these diverse functions. Immunotherapies that directly increase $\mathrm{T}$ cell cytotoxic activity, such as immune checkpoint blockade therapies and adoptive cell transfer therapies, are currently used clinically for cancer treatment and are in development for additional diseases including HIV $[3,4]$. Immunotherapies that enhance regulatory $\mathrm{T}$ cell $\left(\mathrm{T}_{R E G}\right)$ behaviors are in development to treat transplant rejection and autoimmune diseases, including diabetes and Crohn's disease [5-7]. Due to the variable behaviors of $\mathrm{T}$ cell subsets, full evaluation of immunotherapy efficacy requires profiling of $\mathrm{T}$ cell subtypes and activation states to assess the impact of different $\mathrm{T}$ cell compartments on the patient, select for appropriate therapeutic cell populations, and evaluate the degree of response upon stimulation.

New tools that are non-destructive and label-free are needed to fully characterize T cells for assessment of immunotherapies. Currently, T cell subtype and function is determined from expression of surface proteins (e.g. CD3, CD4, CD8, CD45RA, etc.) and cytokine production (e.g. IFN- $\gamma$, TGF- $\beta$, IL-2, IL-4, IL-17, etc.) by antibody-based methods such as flow cytometry, immunohistochemistry, or immunofluorescence, or by transgenic fluorophore expression. However, all of these methods require exogenous contrast agents, and flow cytometry and immunohistochemistry require tissue dissociation and fixation, respectively. A non-destructive and label-free method of determining $\mathrm{T}$ cell activity would enable direct observation of $\mathrm{T}$ cell behavior and immunotherapy effects in vivo in preclinical models of cancer. Additionally, such a tool could be amenable for single-cell quality control of adoptive $\mathrm{T}$ cell therapies, where $\mathrm{T}$ cells, expanded in vitro, are injected into the patient. Autofluorescence imaging is an attractive method to probe immune cell behaviors because it is non-destructive, relies on endogenous contrast, and provides high spatial and temporal resolution.

Fluorescence imaging of the endogenous metabolic co-enzymes NAD $(\mathrm{P}) \mathrm{H}$ and FAD provides quantitative endpoints of cellular metabolism [8-10]. (NADH and NADPH fluorescence are indistinguishable; therefore, 
$\mathrm{NAD}(\mathrm{P}) \mathrm{H}$ is used to represent the combined fluorescence signal[11].) The optical redox ratio is the fluorescence intensity of $\mathrm{NAD}(\mathrm{P}) \mathrm{H}$ divided by the sum of the fluorescence intensities of $\mathrm{NAD}(\mathrm{P}) \mathrm{H}$ and FAD, and provides an optical measurement of the redox state of the cell $[8,12]$. The fluorescence lifetime, the time the fluorophore is in the excited state before returning to ground state, provides information on the protein binding of $\mathrm{NAD}(\mathrm{P}) \mathrm{H}$ and $\mathrm{FAD}[9,13]$. NAD $(\mathrm{P}) \mathrm{H}$ and FAD can both exist in two conformations: a quenched and unquenched form, with a short and long lifetime, respectively. NAD $(\mathrm{P}) \mathrm{H}$ has a short lifetime in the free state and a long lifetime in its protein-bound state [9]. Conversely, FAD has a short lifetime when bound to an enzyme and a long lifetime when free [13]. Fluorescence lifetime imaging (FLIM) allows quantification of the short $\left(\tau_{1}\right)$ and long $\left(\tau_{2}\right)$ lifetime values, the fraction of free and protein-bound co-enzyme ( $\alpha_{1}$ and $\alpha_{2}$, respectively, for $\mathrm{NAD}(\mathrm{P}) \mathrm{H}$, and $\alpha_{2}$ and $\alpha_{1}$, respectively, for $\mathrm{FAD}$ ), and the mean lifetime (the weighted average of the short and long lifetimes, $\left.\tau_{m}=\alpha_{1} * \tau_{1}+\alpha_{2} * \tau_{2}\right)$. The fluorescence intensity and lifetime of $\mathrm{NAD}(\mathrm{P}) \mathrm{H}$ and $\mathrm{FAD}$ are sensitive to metabolic differences between neoplasias and malignant tissues, anti-cancer drug effects in cancer cells, and differentiating stem cells [14-19]. Autofluorescence imaging has been used previously to identify macrophages in vivo and detect metabolic changes due to macrophage polarization [20-22]. Altogether, fluorescence lifetime imaging of $\mathrm{NAD}(\mathrm{P}) \mathrm{H}$ and FAD provide quantitative and functional endpoints of cellular metabolism.

$\mathrm{T}$ cells undergo metabolic reprogramming when activated by an antigen. Upon activation, $\mathrm{T}$ cells have increased metabolic demands to support cell growth, proliferation, and differentiation [23]. CD28 stimulation induces glucose uptake and glycolysis in T cells through upregulation of GLUT1, phosphatidylinositol 3'kinase (PI3K), and Akt. This metabolic state of increased aerobic glycolysis is required for $\mathrm{T}$ cells to maintain effector function [23-25]. Therefore, this study tests the hypothesis that fluorescence lifetime imaging of $\mathrm{NAD}(\mathrm{P}) \mathrm{H}$ and $\mathrm{FAD}$ provides a label-free, non-destructive method with quantitative endpoints to identify activated $\mathrm{T}$ cells. To test this hypothesis, we isolated $\mathrm{T}$ cells from the blood of healthy donors, activated the cells in an antigen-independent manner with a tetrameric antibody (anti-CD2/CD3/CD28) and imaged the $\mathrm{NAD}(\mathrm{P}) \mathrm{H}$ and FAD fluorescence intensity and lifetime of quiescent and activated T cells. This is the first study to (1) demonstrate autofluorescence lifetime differences between quiescent and activated T cells and (2) accurately classify $\mathrm{T}$ cell activation state from machine learning models using quantitative endpoints from autofluoresence lifetime images. 


\section{Results}

\subsection{Autofluorescence imaging reveals metabolic differences with activation in T cells.}

$\mathrm{T}$ cell isolations for $\mathrm{CD}^{+}$(pan-T cell marker) and $\mathrm{CD} 3^{+} \mathrm{CD} 8^{+}$cells were used to study all $\mathrm{T}$ cells, as might be utilized in adoptive cell transfer therapies, and the cytotoxic $\mathrm{CD} 3^{+} \mathrm{CD} 8^{+}$sub-population, respectively. $\mathrm{NAD}(\mathrm{P}) \mathrm{H}$ and FAD autofluorescence imaging reveals metabolic differences in quiescent and activated $\mathrm{T}$ cells (Fig. 1, S1). The high resolution multiphoton imaging allows visualization of bulk $\mathrm{CD}^{+}$and isolated $\mathrm{CD}^{+}{ }^{+} \mathrm{CD} 8^{+} \mathrm{T}$ cells $($ Fig. 1A). In the autofluorescence images, the nucleus remains dark as $\mathrm{NAD}(\mathrm{P}) \mathrm{H}$ is primarily located in the cytoplasm and mitochondria, and FAD is primarily in the mitochondria. Immunofluorescence labeling of CD4, CD8, and CD69 surface proteins verified cell type and activation (Fig. S2). There were significant differences in cell size, optical redox ratio, $\mathrm{NAD}(\mathrm{P}) \mathrm{H} \tau_{m}, \mathrm{NAD}(\mathrm{P}) \mathrm{H} \alpha_{1}$, and $\mathrm{FAD} \alpha_{1}$ between quiescent and activated T cells $\left(\mathrm{p}<0.001\right.$, Fig. 1B-F). Significant changes $(\mathrm{p}<0.001)$ in FAD $\tau_{m}$ between quiescent and activated $\mathrm{T}$ cells were found only for $\mathrm{T}$ cells within the bulk CD3 ${ }^{+} \mathrm{T}$ cell population (Fig. 1E). Additionally, significant changes $(\mathrm{p}<0.001)$ in the short and long lifetimes were observed between quiescent and activated $\mathrm{CD}^{+}$and $\mathrm{CD} 3^{+} \mathrm{CD} 8^{+} \mathrm{T}$ cells (Fig. S1). These differences in autofluorescence endpoints were consistent across the 6 donors (Fig. 1, S1), at 24 and $48 \mathrm{hr}$ of exposure to the activating antibodies (Fig. S3), and between experiments from two different blood draws (183 days apart) from the same donor (Fig. S4). A slight increase in FAD $\tau_{1}$ was found in both quiescent and activated CD3 ${ }^{+} \mathrm{T}$ cells, suggesting a slight change in the microenvironment of bound FAD between $\mathrm{CD}^{+} \mathrm{T}$ cells of the same donor from two blood draws; however, no other autofluorescence endpoints were signficantly different between the two blood draws.

Seahorse OCR and ECAR measurements confirm increased metabolic rates of the activated $\mathrm{T}$ cells $(\mathrm{p}<0.001$, Fig. 1H-J). In a metabolic inhibitor experiment (Fig. S5), the redox ratio of activated T cells decreased $(\mathrm{p}<0.001)$ with a glycolysis inhibitor $(2$-deoxy-d-glucose), and the redox ratio of quiescent $\mathrm{T}$ cells increased $(\mathrm{p}<0.001)$ with oxidative phosphorylation inhibitors (antimycin A and rotenone). Additionally, the glutaminolysis inhibitor BPTES significantly decreased $(\mathrm{p}<0.001)$ the optical redox ratio, NAD $(\mathrm{P}) \mathrm{H} \tau_{m}$, and FAD $\tau_{m}$ of both quiescent and activated $\mathrm{T}$ cells, suggesting a significant contribution of glutaminolysis to the metabolism of quiescent and activated T cells (Fig. S5). 
A
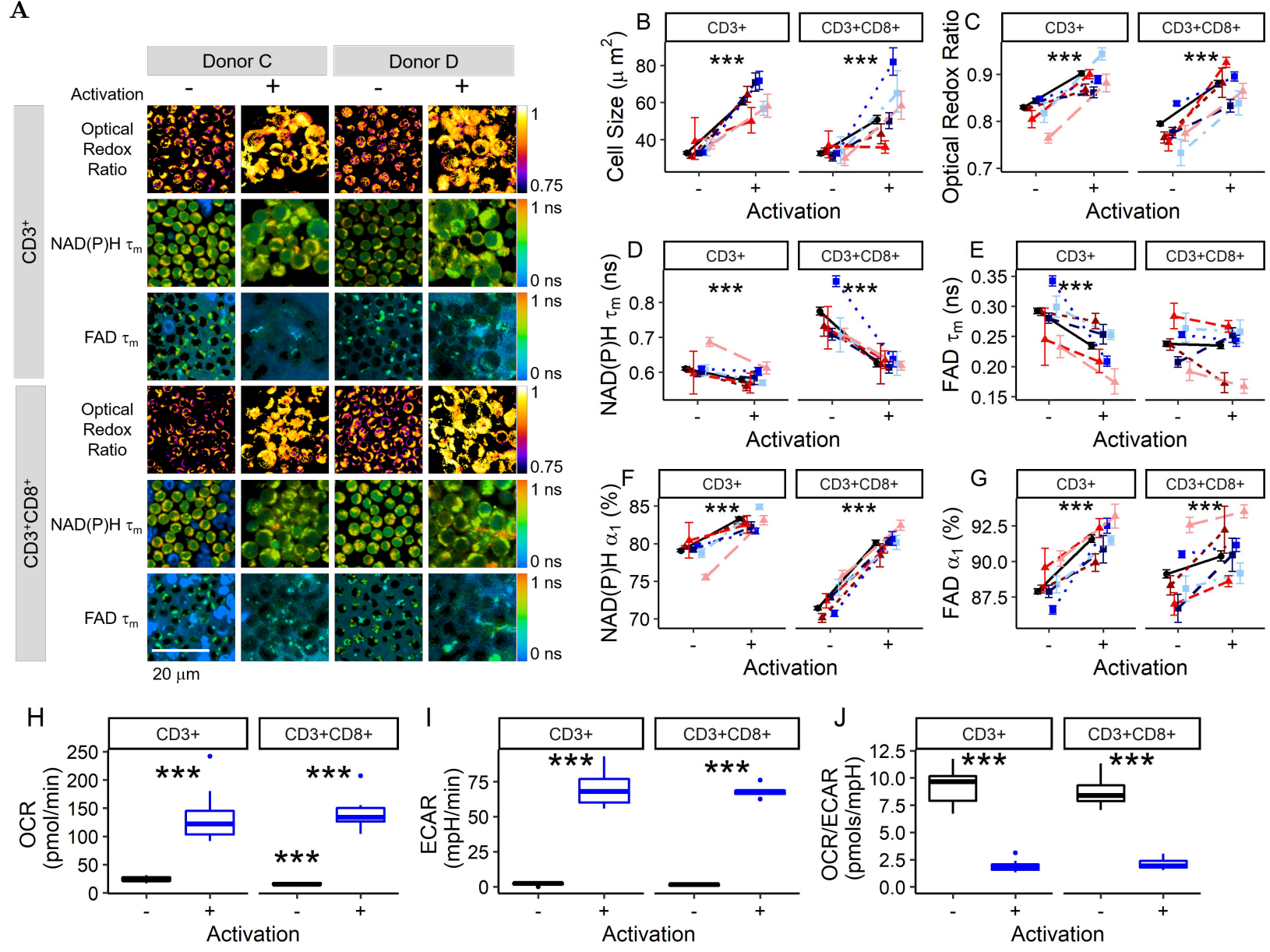

Figure 1: $\mathbf{N A D}(\mathbf{P}) \mathbf{H}$ and FAD autofluorescence imaging reveals metabolic differences between quiescent and activated T cells. Representative optical redox ratio, $\mathrm{NAD}(\mathrm{P}) \mathrm{H} \tau_{m}$, and $\mathrm{FAD} \tau_{m}$ images of quiescent (columns 1,3) and activated (columns 2, 4) $\mathrm{CD}^{+}$(rows 1-3) and CD3 ${ }^{+} \mathrm{CD} 8^{+}$(row 4-6) $\mathrm{T}$ cells from two different donors. Scale bar is $20 \mu \mathrm{m}$. Cell size (B), optical redox ratio (C), NAD(P)H $\tau_{m}(\mathrm{D})$, FAD $\tau_{m}(\mathrm{E}), \mathrm{NAD}(\mathrm{P}) \mathrm{H} \alpha_{1}(\mathrm{~F})$, and FAD $\alpha_{1}(\mathrm{G})$ of quiescent and activated $\mathrm{CD} 3^{+}$and $\mathrm{CD}^{+}{ }^{+} \mathrm{CD} 8^{+} \mathrm{T}$ cells. Black circles represent mean of all data (6 donors), triangles (donors $\mathrm{A}$ [dark red], B [medium red], and $\mathrm{F}$ [light red]) represent data from female donors, squares (donors C [dark blue], D [medium blue], and E [light blue]) represent data from male donors. Each color shade represents data from an individual donor. Data are mean $+/-99 \%$ CI. ${ }^{* * *} \mathrm{p}<0.001 . \mathrm{n}=54-1058$ cells per donor per group. (H-J) Cellular respiration increases in activated $\mathrm{T}$ cells. The oxygen consumption rate $(\mathrm{OCR}$; panel $\mathrm{H})$ and extracellular acidification rate (ECAR, panel I) are increased in activated bulk $\mathrm{CD} 3^{+}$and isolated $\mathrm{CD} 3^{+} \mathrm{CD} 8^{+} \mathrm{T}$ cells. The ratio of OCR to ECAR $(\mathrm{J})$ is significantly decreased in activated bulk $\mathrm{CD} 3^{+}$and isolated $\mathrm{CD} 3^{+} \mathrm{CD} 8^{+} \mathrm{T}$ cells as compared with that of quiescent $\mathrm{T}$ cells. ${ }^{* * *} \mathrm{p}<0.001$, Student's t-test, $\mathrm{n}=6$ wells/group $\mathrm{CD} 3^{+} \mathrm{CD}^{+}$isolation, $\mathrm{n}=12$ wells/group $\mathrm{CD}^{+}$isolation. 


\subsection{Machine learning models of autofluorescence imaging endpoints allow clas- sification of quiescent and activated $\mathrm{T}$ cells with high accuracy.}

Uniform Manifold Approximate and Projection (UMAP) [26], a dimension reduction technique similar to tSNE, was used to visualize how cells cluster from autofluorescence measurements. Neighbors were defined through a cosine distance function computed across the autofluorescence endpoints (optical redox ratio, $\mathrm{NAD}(\mathrm{P}) \mathrm{H} \tau_{m}, \mathrm{NAD}(\mathrm{P}) \mathrm{H} \tau_{1}, \mathrm{NAD}(\mathrm{P}) \mathrm{H} \tau_{2}, \mathrm{NAD}(\mathrm{P}) \mathrm{H} \alpha_{1}, \mathrm{FAD} \tau_{m}, \mathrm{FAD} \tau_{1}, \mathrm{FAD} \tau_{2}$, and FAD $\left.\alpha_{1}\right)$ and cell size for each cell. UMAP was chosen over other techniques, notably PCA or tSNE, for its speed, ability to include non-metric distance functions, and performance on preserving the global structure of the data. UMAP representations of the autofluorescence imaging data reveals separation of quiescent and activated T cells (Fig. 2A-B). The gain ratio of autofluorescence endpoints indicates that $\mathrm{NAD}(\mathrm{P}) \mathrm{H} \alpha_{1}$, cell size, and optical redox ratio are the most important features for classification of activation state of $\mathrm{CD}^{+} \mathrm{T}$ cells (Fig. 2C), and $\mathrm{NAD}(\mathrm{P}) \mathrm{H} \alpha_{1}$, optical redox ratio, and $\mathrm{NAD}(\mathrm{P}) \mathrm{H} \tau_{m}$ are the most important features for classification of activation state of $\mathrm{CD}^{+} \mathrm{CD} 8^{+} \mathrm{T}$ cells (Fig. 2C). The order of feature importance was consistent across multiple feature selection methods including information gain, $\chi^{2}$, and random forest (Fig. S6). Correlation analysis revealed that $\mathrm{NAD}(\mathrm{P}) \mathrm{H} \alpha_{1}$, cell size, and the optical redox ratio are not significantly correlated (Fig. S7), suggesting these features are independent and provide complementary information for classification. $\mathrm{NAD}(\mathrm{P}) \mathrm{H} \alpha_{1}$ and $\tau_{m}$ are significantly correlated (Fig. S7), as expected, given that $\tau_{m}$ is computed from $\alpha_{1}$. Similar feature weight and order of importance were observed from analysis without $\mathrm{NAD}(\mathrm{P}) \mathrm{H} \tau_{m}$ and FAD $\tau_{m}$ (Fig. S8), indicating that the multivariate models were not significantly affected by the correlations between the mean lifetimes and the lifetime components.

Classification models were developed to predict T cell activation state from $\mathrm{NAD}(\mathrm{P}) \mathrm{H}$ and FAD autofluorescence imaging endpoints (Fig. 2D-F). To protect against over-fitting, models were trained on data from 4 donors with activation state assigned from culture conditions and tested on data with same-cell CD69 expression immunofluorescence validation from 3 donors (completely independent and non-overlapping observations). Receiver operator characteristic (ROC) curves reveal high classification accuracy for predicting activation in bulk $\mathrm{CD}^{+}(\mathrm{AUC}=0.975)$ and isolated $\mathrm{CD} 3^{+} \mathrm{CD} 8^{+}(\mathrm{AUC}=0.996) \mathrm{T}$ cells, when the models use all autofluorescence endpoints (optical redox ratio, cell size, $\mathrm{NAD}(\mathrm{P}) \mathrm{H} \tau_{m}, \mathrm{NAD}(\mathrm{P}) \mathrm{H} \tau_{1}, \mathrm{NAD}(\mathrm{P}) \mathrm{H} \tau_{2}$, $\operatorname{NAD}(\mathrm{P}) \mathrm{H} \alpha_{1}, \operatorname{FAD} \tau_{m}, \operatorname{FAD} \tau_{1}, \operatorname{FAD} \tau_{2}$, and FAD $\left.\alpha_{1}\right)$. When the NAD(P)H and FAD autofluorescence imaging endpoints of the $\mathrm{T}$ cells are normalized within a donor to the mean value of the quiescent $\mathrm{CD}^{+}$ population, the ROC AUC decreases to 0.857 for $\mathrm{CD}^{+} \mathrm{T}$ cells (Fig. 2D) and increases slightly to 0.998 for isolated $\mathrm{CD}^{+} \mathrm{CD}^{+} \mathrm{T}$ cells. While all $10 \mathrm{NAD}(\mathrm{P}) \mathrm{H}$ and $\mathrm{FAD}$ autofluorescence features achieved the highest classification accuracy $(\mathrm{AUC}=0.975)$ for activation of $\mathrm{CD} 3^{+} \mathrm{T}$ cells, a model using only $\mathrm{NAD}(\mathrm{P}) \mathrm{H}$ 
$\alpha_{1}$ achieved a slightly lower accuracy of 0.965 (Fig. 2E). Models that include cell size or cell size and the optical redox ratio, endpoints that can be obtained from fluorescence intensity images, were less effective at accurately predicting activation of bulk $\mathrm{CD}^{+} \mathrm{T}$ cells with ROC AUCs of 0.708 and 0.901 , respectively (Fig. 2E). Similar results were obtained for the isolated $\mathrm{CD} 3^{+} \mathrm{CD} 8^{+} \mathrm{T}$ cells, with the highest ROC AUC values achieved for logistic regression classification models using all 10 autofluorescence imaging endpoints and $\mathrm{NAD}(\mathrm{P}) \mathrm{H} \alpha_{1}$ alone, $\mathrm{AUC}=0.996$ and 0.994, respectively (Fig. 2F). Similar classification accuracy was achieved with random forest and support vector machine models using all 10 autofluorescence imaging endpoints (Fig. S9).


Figure 2: Autofluorescence imaging endpoints allow classification of quiescent and activated T cells. (A-B) UMAP data reduction technique allows visual representation of the separation between quiescent ("Q") and activated ("Act") bulk CD3 ${ }^{+}$(A) and isolated CD3 ${ }^{+} \mathrm{CD} 8^{+}$(B) T cells. Each color shade corresponds to a different donor, grays correspond to quiescent cells and green or purple to activated CD3 ${ }^{+}$ or $\mathrm{CD} 3^{+} \mathrm{CD} 8^{+} \mathrm{T}$ cells, respectively. (C) Feature weights for classification of quiescent versus activated $\mathrm{T}$ cells by the gain ratio method. (D) ROC curves for logistic regression models for classification of activation state within bulk CD3 ${ }^{+} \mathrm{T}$ cells, bulk $\mathrm{CD} 3^{+} \mathrm{T}$ cells normalized within each donor (CD3 ${ }^{+}$Norm), isolated $\mathrm{CD} 3^{+} \mathrm{CD} 8^{+} \mathrm{T}$ cells, and isolated $\mathrm{CD} 3^{+} \mathrm{CD} 8^{+} \mathrm{T}$ cells normalized within each donor $\left(\mathrm{CD} 3^{+} \mathrm{CD} 8^{+}\right.$Norm). (E-F) ROC curves for logistic regression classification models computed using different features for the classification of $(\mathrm{E})$ quiescent or activated bulk $\mathrm{CD} 3^{+}$or $(\mathrm{F})$ isolated $\mathrm{CD} 3^{+} \mathrm{CD} 8^{+} \mathrm{T}$ cells. Models were trained on cells that lacked same cell validation data from donors $\mathrm{A}, \mathrm{B}, \mathrm{C}$, and D but were known to be quiescent or activated by culture conditions $\left(\mathrm{n}=4131 \mathrm{CD}^{+}\right.$cells, $\mathrm{n}=2655 \mathrm{CD} 3^{+} \mathrm{CD} 8^{+}$cells), and cells from donors $\mathrm{B}, \mathrm{E}$, and $\mathrm{F}$ with CD69 validation of activation state were used to test the models $(\mathrm{n}=696$ $\mathrm{CD}^{+}$cells, $\mathrm{n}=595 \mathrm{CD} 3^{+} \mathrm{CD} 8^{+}$cells). 


\subsection{Autofluorescence imaging reveals $\mathrm{T}$ cell heterogeneity within and across donors.}

T cell heterogeneity was assessed within and across donors (Fig. 3). Heatmap representation (Fig. 3A) of the z-score of autofluorescence imaging endpoint values at the donor level (each row is the mean data of a single donor, cell type, and activation) reveals that the $\mathrm{T}$ cells cluster by activation state (i.e. quiescent and activated cluster separately) and isolation (bulk $\mathrm{CD} 3^{+}$or isolated $\mathrm{CD} 3^{+} \mathrm{CD} 8^{+}$). Corresponding coefficient of variation heatmaps highlight the high intra-donor variability of the size of activated $\mathrm{T}$ cells and low intra-donor heterogeneity of the autofluorescence endpoints (Fig. S10).

A representative z score heatmap where each row is a single cell from one donor reveals distinct clusters of $\mathrm{T}$ cells by autofluorescence imaging endpoints within the quiescent and activated $\mathrm{CD} 3^{+} \mathrm{CD} 8^{+} \mathrm{T}$ cell populations (Fig. 3B). Multiple quiescent and activated T cell populations were observed across all six donors and arises from varied distributions of autofluorescence imaging endpoints within the T cell populations (Fig. $3 \mathrm{C}$, S11-12). For example, histograms of the $\mathrm{NAD}(\mathrm{P}) \mathrm{H} \tau_{m}$ values of quiescent and activated $\mathrm{CD} 3^{+} \mathrm{CD} 8^{+} \mathrm{T}$ cells reveals a bimodal population within the quiescent $\mathrm{CD} 3^{+} \mathrm{CD} 8^{+} \mathrm{T}$ cells, with one peak of the quiescent cells consistent with the peak of the activated cells (Fig. 3C).

We hypothesized that memory and naïve $\mathrm{T}$ cells within the quiescent population contributed to the observed heterogeneity within the quiescent $\mathrm{CD} 3{ }^{+} \mathrm{CD} 8{ }^{+} \mathrm{T}$ cell population (Fig. 3B-C, S11-13) (i.e. the multiple clusters of quiescent $\mathrm{CD}^{+}{ }^{+} \mathrm{CD} 8^{+}$cells within the heatmaps and bimodal distribution of the $\mathrm{NAD}(\mathrm{P}) \mathrm{H} \tau_{m}$ of quiescent $\mathrm{CD}^{+}{ }^{+} \mathrm{CD} 8{ }^{+} \mathrm{T}$ cells). To test this, we co-stained quiescent $\mathrm{CD} 3^{+} \mathrm{CD} 8^{+} \mathrm{T}$ cells with antibodies against CD45RA, a marker of naïve T cells, and CD45RO, a marker of memory T cells. NAD $(\mathrm{P}) \mathrm{H} \tau_{m}$ was significantly decreased in $\mathrm{CD} 45 \mathrm{RO}^{+}$cells as compared with $\mathrm{NAD}(\mathrm{P}) \mathrm{H} \tau_{m}$ of $\mathrm{CD}^{2} 5 \mathrm{RA}^{+}$cells (Fig. 3D). Additionally, the optical redox ratio and $\mathrm{NAD}(\mathrm{P}) \mathrm{H} \alpha_{1}$ were increased $(\mathrm{p}<0.01)$ in $\mathrm{CD}_{45 \mathrm{RO}^{+}} \mathrm{CD}^{+} \mathrm{CD}^{+}$ T cells as compared to CD45RA ${ }^{+}$cells (Fig. S14).

\subsection{Culture with $\mathrm{CD}^{+} \mathrm{CD}^{+}{ }^{+} \mathrm{T}$ cells affects the autofluorescence of $\mathrm{CD}^{+} \mathrm{CD}^{+}$ T cells}

$\mathrm{NAD}(\mathrm{P}) \mathrm{H}$ and FAD autofluorescence imaging endpoints reveal metabolic differences between $\mathrm{CD}^{+} \mathrm{CD}^{+} \mathrm{T}$ cells cultured as an isolated population and $\mathrm{CD} 3^{+} \mathrm{CD} 8^{+} \mathrm{T}$ cells cultured with $\mathrm{CD} 3^{+} \mathrm{CD} 4^{+} \mathrm{T}$ cells $\left(\mathrm{bulk} \mathrm{CD} 3^{+}\right.$ isolation). A UMAP (data dimension reduction) representation of $\mathrm{NAD}(\mathrm{P}) \mathrm{H}$ and FAD autofluorescence imaging endpoints reveals that $\mathrm{CD} 3{ }^{+} \mathrm{CD} 8^{+} \mathrm{T}$ cells cultured from the $\mathrm{CD} 3^{+} \mathrm{CD} 8^{+}$specific $\mathrm{T}$ cell isolations cluster separately from $\mathrm{CD}^{+} \mathrm{CD} 8^{+} \mathrm{T}$ cells within bulk $\mathrm{CD} 3^{+} \mathrm{T}$ cell populations (Fig. 4A). The optical redox ratio and $\mathrm{NAD}(\mathrm{P}) \mathrm{H} \alpha_{1}$ are decreased in both quiescent and activated $\mathrm{CD} 3^{+} \mathrm{CD} 8^{+} \mathrm{T}$ cells of the isolated 
A
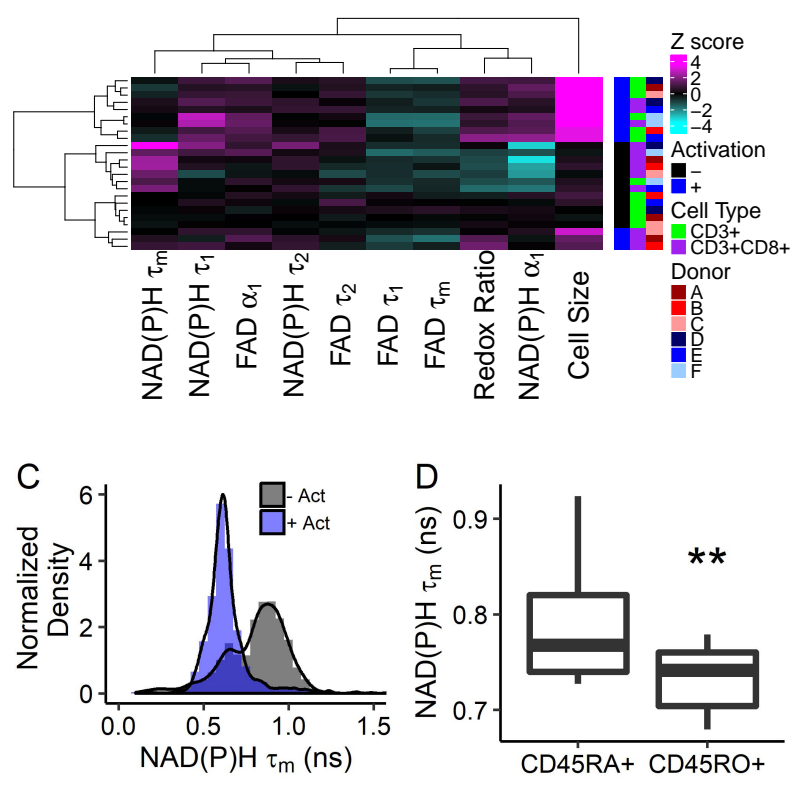

B

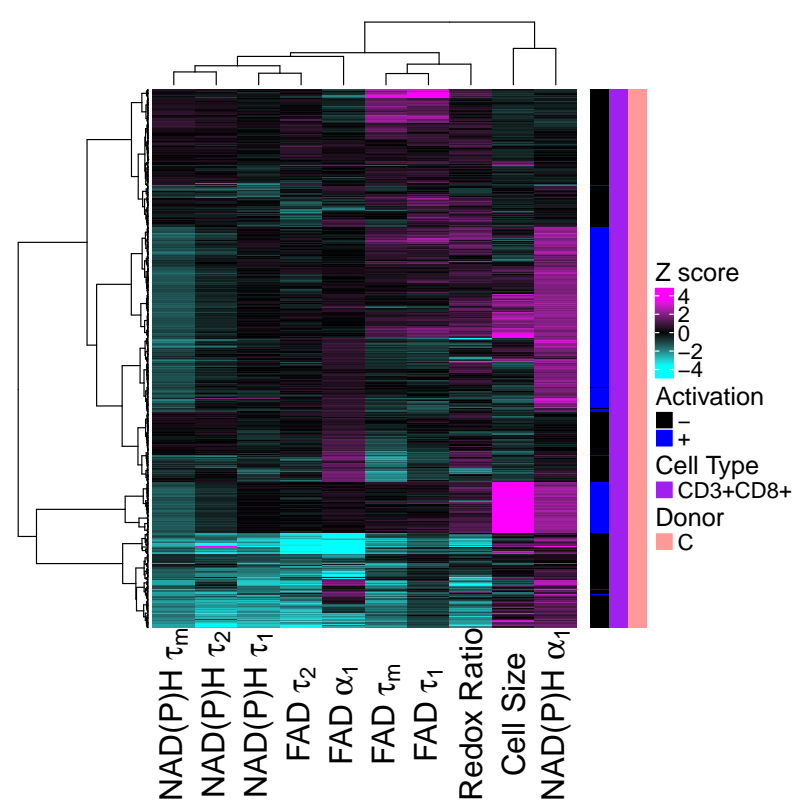

Figure 3: Autofluorescence imaging reveals inter- and intra-donor $\mathbf{T}$ cell heterogeneity. (A) Heatmap of z-scores of $\mathrm{NAD}(\mathrm{P}) \mathrm{H}$ and FAD autofluorescence imaging endpoints where each row is the mean data representing a single donor, subtype $\left(\mathrm{CD} 3^{+}\right.$or $\left.\mathrm{CD} 3^{+} \mathrm{CD} 8^{+}\right)$, and activation. Data clusters by activation state and isolation (bulk $\mathrm{CD} 3^{+}$or isolated $\mathrm{CD} 3^{+} \mathrm{CD} 8^{+}$). (B) Heatmap of z-scores of NAD $(\mathrm{P}) \mathrm{H}$ and FAD autofluorescence imaging endpoints of $\mathrm{CD} 3^{+} \mathrm{CD} 8^{+} \mathrm{T}$ cells from a single donor, each row is a single cell $\left(\mathrm{n}=635\right.$ cells). Distinct clusters are identified within the quiescent and activated $\mathrm{CD} 3^{+} \mathrm{CD} 8^{+} \mathrm{T}$ cells. (C) Histogram analysis of $\mathrm{NAD}(\mathrm{P}) \mathrm{H} \tau_{m}$ reveals two populations in quiescent $\mathrm{CD} 3^{+} \mathrm{CD} 8^{+} \mathrm{T}$ cells across all donors ( $\mathrm{n}=2126$ quiescent cells, 1352 activated cells). (D) $\mathrm{NAD}(\mathrm{P}) \mathrm{H} \tau_{m}$ is decreased in CD45RO+ CD3 ${ }^{+} \mathrm{CD} 8^{+} \mathrm{T}$ cells compared to $\mathrm{NAD}(\mathrm{P}) \mathrm{H} \tau_{m}$ of $\mathrm{CD}_{45 \mathrm{RA}}{ }^{+} \mathrm{CD}^{+}{ }^{+} \mathrm{CD} 8^{+} \mathrm{T}$ cells $\left(\mathrm{CD} 45 \mathrm{RA}{ }^{+} \mathrm{n}=27\right.$ cells, CD45RO ${ }^{+} \mathrm{n}=11$ cells from 1 donor, ${ }^{* *} \mathrm{p}<0.01$, - Act $=$ quiescent cells, + Act $=$ cells exposed to anti-CD3/CD2/CD28 for $48 \mathrm{hr}$.) 
$\mathrm{CD}^{+}{ }^{+} \mathrm{CD} 8^{+}$population as compared to the corresponding values of quiescent and activated $\mathrm{CD} 3^{+} \mathrm{CD} 8^{+} \mathrm{T}$ cells, respectively, within the bulk $\mathrm{CD}^{+}$population (Fig. 4B-C). Additional differences in $\mathrm{NAD}(\mathrm{P}) \mathrm{H}$ and FAD autofluorescence lifetime endpoints were observed between $\mathrm{CD} 3^{+} \mathrm{CD} 8^{+} \mathrm{T}$ cells within the bulk $\mathrm{CD} 3^{+}$ population and the isolated $\mathrm{CD} 3^{+} \mathrm{CD} 8^{+}$population (Fig. S15).

Despite these differences between $\mathrm{CD} 3^{+} \mathrm{CD} 8^{+} \mathrm{T}$ cells of $\mathrm{CD} 3^{+} \mathrm{CD} 8^{+}$specific isolations and bulk $\mathrm{CD} 3^{+}$ isolations, significant changes in $\mathrm{NAD}(\mathrm{P}) \mathrm{H}$ and FAD autofluorescence endpoints due to activation are maintained, and classification models predict activation status of $\mathrm{CD} 3^{+} \mathrm{CD} 8^{+}$cells with high accuracy regardless of isolation (Fig. 4D). Random forest feature selection revealed that $\mathrm{NAD}(\mathrm{P}) \mathrm{H} \alpha_{1}$ is the most important feature for classification of quiescent from activated $\mathrm{CD} 3^{+}$or $\mathrm{CD} 3^{+} \mathrm{CD} 8^{+} \mathrm{T}$ cells (Fig. S16A).

\subsection{Machine learning models of autofluorescence endpoints classify $\mathrm{CD}^{+} \mathrm{CD}^{+}$ from $\mathrm{CD}^{+} \mathrm{CD}^{+} \mathrm{T}$ cells within bulk $\mathrm{CD}^{+}$populations}

Heterogeneity in $\mathrm{NAD}(\mathrm{P}) \mathrm{H}$ and $\mathrm{FAD}$ autofluorescence endpoints between $\mathrm{CD} 3^{+} \mathrm{CD} 4^{+}$and $\mathrm{CD} 3^{+} \mathrm{CD} 8^{+} \mathrm{T}$ cells was observed within the T cells from the bulk CD3 ${ }^{+}$isolation. A UMAP representation of the NAD(P)H and FAD autofluorescence data allows visualization of the clustering and separation of quiescent and activated $\mathrm{CD}^{+}{ }^{+} \mathrm{CD} 4^{+}$and $\mathrm{CD}^{+}{ }^{+} \mathrm{CD} 8^{+} \mathrm{T}$ cells within the bulk CD $3^{+}$isolation (Fig. 4E). These differences between $\mathrm{CD}^{+}{ }^{\mathrm{CD}} 4^{+}$and $\mathrm{CD} 3^{+} \mathrm{CD} 8^{+} \mathrm{T}$ cells are due to significant differences in $\mathrm{NAD}(\mathrm{P}) \mathrm{H}$ and $\mathrm{FAD}$ endpoints, including $\mathrm{NAD}(\mathrm{P}) \mathrm{H} \tau_{2}$, which is increased $(\mathrm{p}<0.05)$ in quiescent $\mathrm{CD} 3^{+} \mathrm{CD} 8^{+} \mathrm{T}$ cells compared to quiescent $\mathrm{CD}^{+}{ }^{+} \mathrm{CD} 4^{+} \mathrm{T}$ cells, and $\mathrm{NAD}(\mathrm{P}) \mathrm{H} \alpha_{1}$, which is decreased in activated $\mathrm{CD} 3^{+} \mathrm{CD} 8^{+} \mathrm{T}$ cells compared to activated $\mathrm{CD}^{+}{ }^{+} \mathrm{CD} 4{ }^{+} \mathrm{T}$ cells $(\mathrm{p}<0.05$, Fig. $4 \mathrm{~F}-\mathrm{G}, \mathrm{S} 17)$. Random forest models to classify $\mathrm{T}$ cell subtype $\left(\mathrm{CD}^{+} \mathrm{CD}^{+}\right.$or $\left.\mathrm{CD}^{+} \mathrm{CD}^{+}\right)$within the bulk $\mathrm{CD} 3^{+} \mathrm{T}$ cell isolation have average predictions of $97.5 \%$ and 99.7\% for separate predictions on subsets of quiescent or activated $\mathrm{T}$ cells, respectively, and $99.4 \%$ for all four groups, when trained on $75 \%$ of the $\mathrm{T}$ cell observations and tested on the remaining $25 \%$ (Fig. $4 \mathrm{H}$ ). Classification accuracy scales with number of cells in train versus test groups (Fig. 4H). Random forest feature analysis revealed that $\mathrm{NAD}(\mathrm{P}) \mathrm{H} \tau_{2}$ is the highest weighted feature for the classification of activated $\mathrm{CD}^{+}{ }^{+} \mathrm{CD} 4^{+}$from activated $\mathrm{CD} 3^{+} \mathrm{CD} 8^{+} \mathrm{T}$ cells, and $\mathrm{FAD} \tau_{1}$ is the highest weighted feature for quiescent $\mathrm{CD}^{+}{ }^{\mathrm{CD}} 4^{+}$from quiescent $\mathrm{CD} 3{ }^{+} \mathrm{CD} 8^{+} \mathrm{T}$ cells (Fig. S16B).

\subsection{Autofluorescence imaging allows classification of activated $\mathrm{T}$ cells in cul- tures of combined quiescent and activated $\mathrm{T}$ cells}

$\mathrm{NAD}(\mathrm{P}) \mathrm{H}$ and FAD autofluorescence imaging allows label-free imaging and classification of $\mathrm{T}$ cell activation in $\mathrm{T}$ cell cultures with combined quiescent and activated cells. A representative $\mathrm{NAD}(\mathrm{P}) \mathrm{H} \alpha_{1}$ image with 

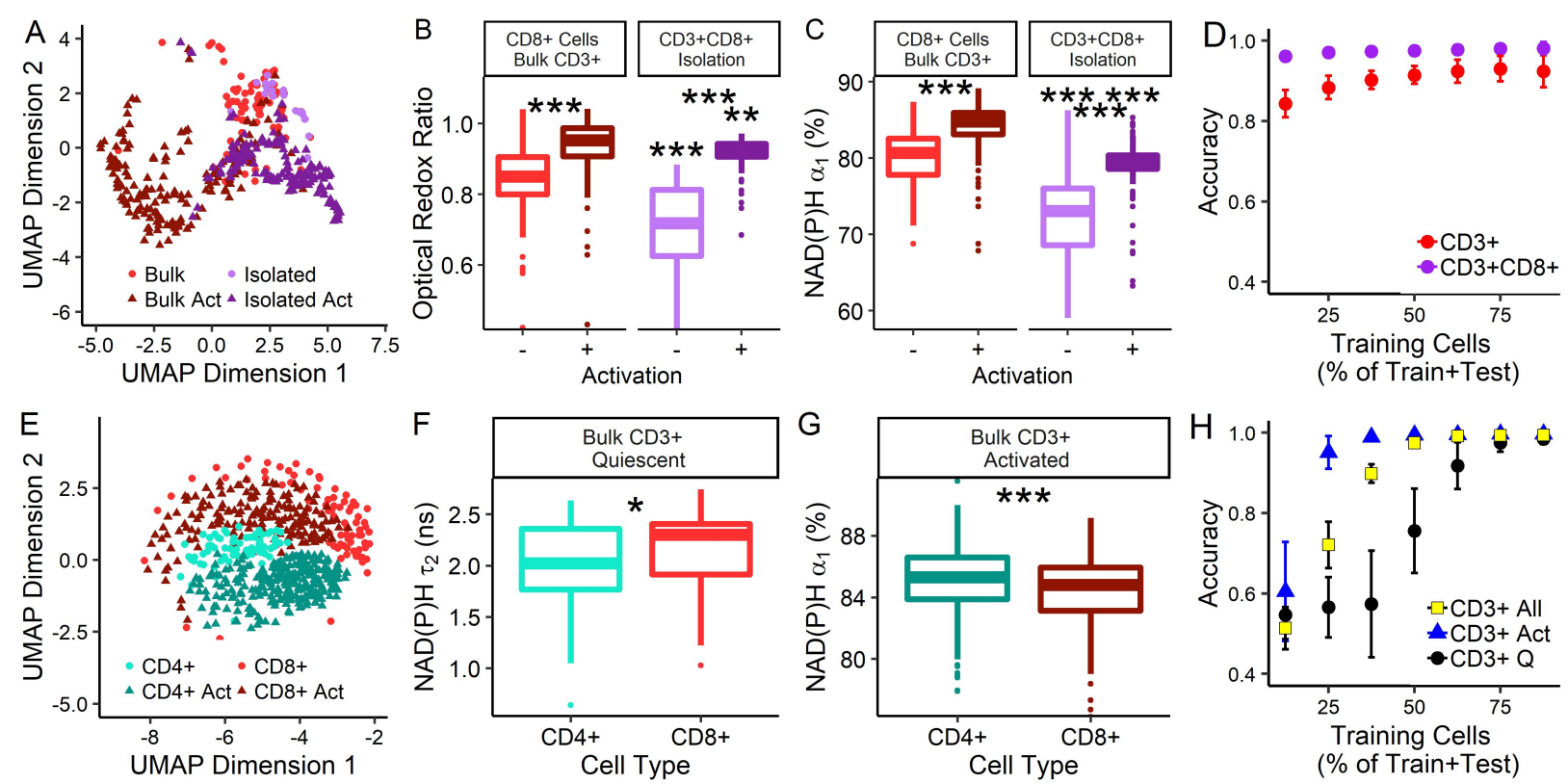

Figure 4: T cell population composition affects T cell autofluorescence. (A) UMAP of NAD(P)H and FAD autofluorescence endpoints of quiescent and activated ("Act") $\mathrm{CD} 3{ }^{+} \mathrm{CD} 8^{+} \mathrm{T}$ cells identified within bulk $\mathrm{CD}^{+}$and specific $\mathrm{CD} 3^{+} \mathrm{CD} 8^{+}$isolations. (B) Optical redox ratio and $(\mathrm{C}) \mathrm{NAD}(\mathrm{P}) \mathrm{H} \alpha_{1}$ of $\mathrm{CD}^{+} \mathrm{CD} 8^{+} \mathrm{T}$ cells cultured as an isolated population $\left(\mathrm{CD}^{+} \mathrm{CD}^{+}\right.$specific isolation, $\mathrm{n}=39$ quiescent cells, $\mathrm{n}=174$ activated cells) and with $\mathrm{CD} 3^{+} \mathrm{CD} 4^{+} \mathrm{T}$ cells (bulk $\mathrm{CD} 3^{+}$isolation, $\mathrm{n}=83$ quiescent cells, $\mathrm{n}=170$ activated cells). Stars between quiescent and activated boxplots compare quiescent and activated $\mathrm{CD} 3^{+} \mathrm{CD} 8^{+} \mathrm{T}$ cells within an isolation $\left(\mathrm{CD}^{+}\right.$or $\left.\mathrm{CD}^{+}{ }^{+} \mathrm{CD} 8^{+}\right)$, stars above the quiescent box plot represent signficance between quiescent $\mathrm{CD}^{+}{ }^{+} \mathrm{CD} 8^{+} \mathrm{T}$ cells from the bulk $\mathrm{CD} 3^{+}$and $\mathrm{CD} 3^{+} \mathrm{CD} 8^{+}$specific isolations, stars above the activated box plot represent signficance between activated $\mathrm{CD} 3^{+} \mathrm{CD} 8^{+} \mathrm{T}$ cells from the bulk $\mathrm{CD} 3^{+}$and $\mathrm{CD} 3^{+} \mathrm{CD} 8^{+}$ specific isolations, ${ }^{* *} \mathrm{p}<0.01,{ }^{* * *} \mathrm{p}<0.001$. (D) Accuracy of random forest classification of quiescent versus activated $\mathrm{CD} 3^{+} \mathrm{CD} 8^{+} \mathrm{T}$ cells from $\mathrm{CD} 3^{+} \mathrm{CD} 8^{+}$specific isolations $(\mathrm{n}=213$ cells $)$ and bulk $\mathrm{CD} 3^{+}$isolations $(\mathrm{n}=253$ cells). (E) UMAP of $\mathrm{NAD}(\mathrm{P}) \mathrm{H}$ and FAD autofluorescence imaging endpoints of quiescent and activated $\mathrm{CD} 3^{+} \mathrm{CD} 4^{+}$and $\mathrm{CD} 3^{+} \mathrm{CD} 8^{+}$cells identified within bulk $\mathrm{CD} 3^{+}$populations. (F) $\mathrm{NAD}(\mathrm{P}) \mathrm{H} \tau_{2}$ of quiescent $\mathrm{CD}^{+}{ }^{+} \mathrm{CD} 4^{+}$and $\mathrm{CD} 3^{+} \mathrm{CD} 8^{+}$cells (bulk $\mathrm{CD} 3^{+}$isolation, $\mathrm{n}=66$ quiescent $\mathrm{CD} 3^{+} \mathrm{CD} 4^{+} \mathrm{T}$ cells, $\mathrm{n}=83$ quiescent $\mathrm{CD} 3^{+} \mathrm{CD} 8^{+} \mathrm{T}$ cells, $\left.{ }^{*} \mathrm{p}<0.05,{ }^{* * *} \mathrm{p}<0.001\right)$. (G) NAD(P)H $\alpha_{1}$ of activated $\mathrm{CD} 3^{+} \mathrm{CD} 4^{+}$and $\mathrm{CD}^{+}{ }^{+} \mathrm{CD} 8^{+}$cells (bulk $\mathrm{CD} 3^{+}$isolation, $\mathrm{n}=264$ activated $\mathrm{CD} 3^{+} \mathrm{CD} 4^{+} \mathrm{T}$ cells, $\mathrm{n}=170$ activated $\mathrm{CD} 3^{+} \mathrm{CD} 8^{+}$ $\mathrm{T}$ cells). $(\mathrm{H})$ Accuracy of random forest classification of $\mathrm{CD} 3^{+} \mathrm{CD} 4^{+}$and $\mathrm{CD} 3^{+} \mathrm{CD} 8^{+} \mathrm{T}$ cells from quiescent (2 group classification, "CD3 ${ }^{+}$Q"), activated (2 group classification, "CD3 ${ }^{+}$Act"), or both quiescent and activated T cells (4 group classification, "CD3 ${ }^{+}$All") within bulk $\mathrm{CD} 3^{+}$isolations, total observations include 66 quiescent $\mathrm{CD} 3{ }^{+} \mathrm{CD} 4^{+} \mathrm{T}$ cells, 83 quiescent $\mathrm{CD} 3^{+} \mathrm{CD} 8^{+} \mathrm{T}$ cells, 264 activated $\mathrm{CD} 3^{+} \mathrm{CD} 4^{+} \mathrm{T}$ cells, and 170 activated $\mathrm{CD} 3^{+} \mathrm{CD} 8^{+} \mathrm{T}$ cells. 
CD69 immunofluorescence overlaid in pink, demonstrates the difference in $\mathrm{NAD}(\mathrm{P}) \mathrm{H} \alpha_{1}$ between quiescent $\left(\mathrm{CD}^{-} 9^{-}\right)$and activated $\left(\mathrm{CD} 69^{+}\right) \mathrm{T}$ cells (Fig. 5A). UMAP visualization of the autofluorescence imaging data reveals separation of quiescent and activated CD3 ${ }^{+} \mathrm{T}$ cells within this population of combined quiescent and activated cells (Fig. 5B). When cultured in isolated populations, quiescent and activated T cells have significantly different $\mathrm{NAD}(\mathrm{P}) \mathrm{H}$ and FAD imaging endpoints, including the optical redox ratio and $\mathrm{NAD}(\mathrm{P}) \mathrm{H}$ $\alpha_{1}$, than their respective counterpart from a combined (quiescent with activated $\mathrm{T}$ cells) population (Fig. 5C-D, Fig. S18). Random forest feature selection for classification of activation status of $\mathrm{T}$ cells within a combined, quiescent and activated, T cell population reveals that $\mathrm{NAD}(\mathrm{P}) \mathrm{H} \alpha_{1}$ is the most important feature for classification, followed by $\mathrm{NAD}(\mathrm{P}) \mathrm{H} \tau_{m}$ (Fig. S19). Logistic regression models to predict activation status of $\mathrm{T}$ cells in a combined, quiescent and activated, CD3 ${ }^{+} \mathrm{T}$ cell culture achieves ROC AUCs of 0.95 when all $10 \mathrm{NAD}(\mathrm{P}) \mathrm{H}$ and FAD imaging endpoints are included, 0.95 and 0.68 when only predicting from $\mathrm{NAD}(\mathrm{P}) \mathrm{H}$ $\alpha_{1}$ or cell size, respectively, and 0.67 for redox ratio and cell size (Fig. 5E).

\subsection{Autofluorescence imaging resolves temporal changes in $\mathrm{T}$ cells with activa- tion}

Metabolic changes occur rapidly within T cells upon activation [27]; therefore, we hypothesized that timecourse imaging of $\mathrm{T}$ cells would resolve changes in $\mathrm{T}$ cell autofluorescence. $\mathrm{NAD}(\mathrm{P}) \mathrm{H}$ fluorescence lifetime images were acquired from $\mathrm{CD}^{+}{ }^{+}$quiescent $\mathrm{T}$ cells immediately after exposure to the activating tetrametic antibody (anti-CD2/CD3/CD28). The NAD(P)H intensity of the nucleus increased by $10 \%$ relative to the pre-activator values, within a few minutes of addition of the activator, and remained consistently higher than the average pre-activation $\mathrm{NAD}(\mathrm{P}) \mathrm{H}$ intensity throughout the time-course (Fig. 5F). NAD $(\mathrm{P}) \mathrm{H}$ intensity within the nucleus may indicate increased transcription [28]. The $\mathrm{NAD}(\mathrm{P}) \mathrm{H}$ intensity in the cytoplasm initially increased $(\mathrm{t}<1 \mathrm{~m})$ and then decreased, relative to the pre-activation $\mathrm{NAD}(\mathrm{P}) \mathrm{H}$ intensity of the cytoplasm. $\mathrm{NAD}(\mathrm{P}) \mathrm{H} \alpha_{1}$ increased significantly in the cytoplasm by $2 \%$ at $\mathrm{t}=6$ minutes post addition of the activator and remained significantly increased until $t=8.75 \mathrm{~m}$. These autofluorescence changes observed early, within minutes of activation, indicate that autofluorescence lifetime imaging is sensitive to robust transcription and metabolic changes that occur with activation in T cells [27].

\section{Discussion}

$\mathrm{T}$ cells are an important component of the adaptive immune response with direct cytotoxic and immunemodulating behaviors. Novel immunotherapies that directly modify $\mathrm{T}$ cell behavior show promise for treating 

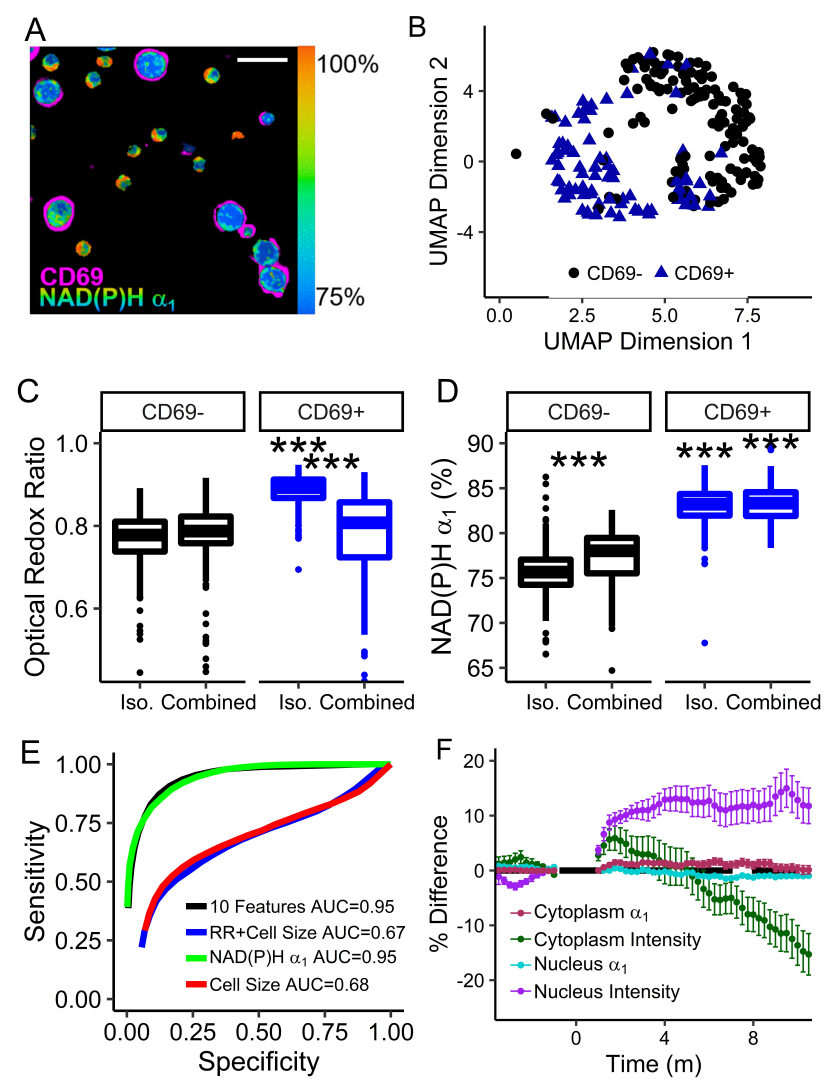

Figure 5: Autofluorescence imaging allows classification of quiescent and activated T cells within combined quiescent and activated $\mathbf{T}$ cell populations. (A) Representative $\mathrm{NAD}(\mathrm{P}) \mathrm{H} \alpha_{1}$ image of combined quiescent $\left(\mathrm{CD} 69^{-}\right)$and activated $\left(\mathrm{CD} 69^{+}\right) \mathrm{T}$ cells with $\mathrm{CD} 69$ immunofluorescence overlaid in pink. Scale bar is $30 \mu \mathrm{m}$. (B) UMAP representation of NAD(P)H and FAD imaging endpoints of CD69and $\mathrm{CD} 69^{+} \mathrm{CD}^{+} \mathrm{T}$ cells from a combined population of quiescent and activated T cells. (C) Optical redox ratio and (D) $\mathrm{NAD}(\mathrm{P}) \mathrm{H} \alpha_{1}$ of isolated ("Iso.") and combined quiescent $\left(\mathrm{CD} 69^{-}\right)$and activated $\left(\mathrm{CD} 69^{+}\right)$ $\mathrm{CD}^{+} \mathrm{T}$ cells. ${ }^{* * *} \mathrm{p}<0.001, \mathrm{n}=289-438$ cells per group, single donor. (E) ROC curves of logistic regression classification of quiescent and activated $\mathrm{CD}^{+} \mathrm{T}$ cells from a combined population of $\mathrm{CD} 69^{-}$and $\mathrm{CD} 69^{+} \mathrm{T}$ cells. (F) Percent difference of $\mathrm{NAD}(\mathrm{P}) \mathrm{H} \alpha_{1}$ and fluorescence intensity in $\mathrm{CD} 3^{+} \mathrm{T}$ cell nuclei and cytoplasms over time. Anti-CD2/CD3/CD28 added at $\mathrm{t}=0 \mathrm{~m}$. mean $+/-\mathrm{SD}$ of 34 cells. 
a variety of conditions including cancer and autoimmune disease. Due to their varied activities, characterization of $\mathrm{T}$ cell function is imperative for assessment of immunotherapy efficacy for pre-clinical evaluation and quality control of clinical immunotherapies. In this study, we develop autofluorescence lifetime imagingbased methods for determination of $\mathrm{T}$ cell activation at the single cell level. Autofluorescence lifetime imaging is non-destructive, label-free, and has high spatial and temporal resolution that is amenable with live cell assessment, longitudinal studies, and in vivo imaging. Autofluorescence imaging offers advantages over antibody-labeling methods that are traditionally used to assess $\mathrm{T}$ cell function with high specificity which are less amenable to non-invasive time-course studies within intact samples.

Upon activation, $\mathrm{T}$ cell metabolism switches from tricarboxylic acid oxidation of glucose and $\beta$-oxidation of fatty acids to glycolysis and glutaminolysis $[23-25,29,30]$. T cells with high glycolytic activity in vitro show poor persistence, low recall responses and low proliferation rates that lead to poor effector activity in vivo, whereas $\mathrm{T}$ cells with high fatty acid oxidation show increased persistence, recall responses and proliferation leading to better effector activity within the tumor [31]. Changes in NAD(P)H and FAD autofluorescence imaging endpoints, including the increased optical redox ratio observed in activated $\mathrm{T}$ cells relative to the optical redox ratio of quiescent $\mathrm{T}$ cells, reflect a shift towards glycolysis in activated $\mathrm{T}$ cells (Fig. 1, S1, S18-19). Significant changes in the lifetimes of protein-bound $\mathrm{NAD}(\mathrm{P}) \mathrm{H}\left(\tau_{2}\right)$ and protein-bound $\mathrm{FAD}\left(\tau_{1}\right.$; Fig. S1) indicate differences in the protein binding partners of $\mathrm{NAD}(\mathrm{P}) \mathrm{H}$ and $\mathrm{FAD}$ [32]. A significant increase in the fraction of free $\mathrm{NAD}(\mathrm{P}) \mathrm{H}\left(\alpha_{1} ;\right.$ Fig. $\left.1 \mathrm{~F}\right)$ in activated $\mathrm{T}$ cells as compared to that of quiescent $\mathrm{T}$ cells, suggests a relative increase in free $\mathrm{NAD}(\mathrm{P}) \mathrm{H}$ and a decrease in protein-bound $\mathrm{NADH}$, consistent with a shift from TCA metabolism to glycolysis [33], which was verified by the Seahorse assay and metabolic inhibitor experiment (Fig. 1H-J, S5). The significant increase in the lifetime of free $\mathrm{NAD}(\mathrm{P}) \mathrm{H}\left(\tau_{1}\right.$, Fig. S1), suggests a change in the microenvironment (e.g., $\mathrm{pH}$, oxygen) of the free fraction of $\mathrm{NAD}(\mathrm{P}) \mathrm{H}$ that reduces the quenching of the fluorophore. Altogether, the significant changes observed between NAD(P)H and FAD fluorescence lifetime values reflect changes in the microenvironment of the metabolic coenzymes $N A D(P) H$ and FAD and altered metabolic pathway utilizition by quiescent and activated T cells [23-25, 29, 30].

$\mathrm{T}$ cells are known to be highly heterogeneous, with phenotypic heterogeneity of surface proteins and effector function observed for $\mathrm{CD} 3^{+} \mathrm{CD} 4^{+}$and $\mathrm{CD} 3^{+} \mathrm{CD} 8^{+} \mathrm{T}$ cells [34]. This heterogeneity can arise from the strength of the activating event, the microenvironment of the $\mathrm{T}$ cell, and differences in gene regulation at the time of activation [35-37]. Heterogeneity analysis, by heatmaps and histograms, revealed heterogeneous clustering of $\mathrm{T}$ cells within the autofluorescence imaging dataset. One of these populations within the quiescent $\mathrm{CD}^{+}{ }^{+} \mathrm{CD} 8^{+}$population, was identified due to a difference in the mean $\mathrm{NAD}(\mathrm{P}) \mathrm{H}$ lifetime which was found to be due to naïve $\left(\mathrm{CD} 45 \mathrm{RO}^{+}\right)$and memory $\left(\mathrm{CD} 45 \mathrm{RA}^{+}\right) \mathrm{CD}^{+} \mathrm{CD} 8^{+} \mathrm{T}$ cells (Fig. 3C-D), which are known to have differing metabolic states: memory $\mathrm{T}$ cells have increased glycolytic capacity and 
mitochondrial mass as compared with naïve T cells [27]. An additional subpopulation was identified within the activated $\mathrm{T}$ cell subset and characterized by larger than average cells (Fig. 3B, S6-7). These large cells may be actively dividing cells, a condition which is also accompanied by metabolic and autofluorescence differences $[38,39]$.

Machine learning approaches are powerful tools for classification of biomedical imaging data and have been used on extracted morphological features of phase-contrast images to identify cancer cells from immune cells, on brightfield images to assess cell cycle, and on phase contrast and autofluorescence images to classify macrophage exposure to LPS $[22,40,41]$. Here, high ROC AUCs $(0.95+)$ were achieved using machine learning techniques to classify $\mathrm{T}$ cells as activated or quiescent using the autofluorescence imaging endpoints (optical redox ratio, cell size, $\mathrm{NAD}(\mathrm{P}) \mathrm{H} \tau_{m}, \mathrm{NAD}(\mathrm{P}) \mathrm{H} \tau_{1}, \mathrm{NAD}(\mathrm{P}) \mathrm{H} \tau_{2}, \mathrm{NAD}(\mathrm{P}) \mathrm{H} \alpha_{1}$, FAD $\tau_{m}$, FAD $\tau_{1}, \mathrm{FAD} \tau_{2}$, and FAD $\alpha_{1}$ ) quantified for each cell. Classification of activation of $\mathrm{T}$ cells from CD3 ${ }^{+} \mathrm{CD} 8^{+}$ specific isoations was slightly higher than that of $\mathrm{T}$ cells from bulk CD3 ${ }^{+}$isolations as might be expected for a homogeneous population $\left(\mathrm{CD} 3^{+} \mathrm{CD} 8^{+}\right)$rather than a heterogeneous population (bulk $\mathrm{CD} 3^{+}$populations contain $\mathrm{CD}^{+}$and $\mathrm{CD}^{+}$subsets). Although multiple classification models were found to have similar performance, logistic regression was the best fitting model, suggesting that the predicted probability of activation is a linear combination of all 10 of the autofluorescence imaging endpoints. Interestingly, donor normalization (Fig. 2D) of the autofluorescence imaging endpoints did not improve classification accuracy, suggesting that the autofluorescence endpoints reflect changes in $\mathrm{T}$ cells with activation that are consistent across donors so generalized models can be used for unspecified donors or patients, which is beneficial for robust implementation of autofluorescence imaging as a universal tool to evaluate $\mathrm{T}$ cell activation.

The models for classification of activation in T cells reported here have higher ROC AUC values than the previously reported accuracy of $84-87 \%$ found for binary logistic regression classification of morphological and Raman spectra features of control and LPS-exposed macrophages [22]. The increased accuracy obtained in our study could be due to the metabolic information gained from the $\mathrm{NAD}(\mathrm{P}) \mathrm{H}$ and FAD autofluorescence signals, differences in the heterogeneity of the measured populations, and/or differing numbers of cells in the training and testing data sets. Although high classification accuracy was achieved with the machine learning approaches, deep learning methods such as neural networks may achieve improvements in classification accuracy, as has been demonstrated for the classification of cancer cells from immune cells in phase-contrast images [40].

$\mathrm{NAD}(\mathrm{P}) \mathrm{H} \alpha_{1}$ was consistently identified as the most important feature for differentiation of quiescent and activated $\mathrm{T}$ cells across different feature selection methods (including gain ratio, information gain, $\chi^{2}$, and random forest), and different subsets of $\mathrm{CD}^{+}, \mathrm{CD}^{+} \mathrm{CD} 8^{+}$, and $\mathrm{CD} 69^{+} / \mathrm{CD} 69^{-} \mathrm{T}$ cells (Fig. 2C, S6, S19). The classification analysis also revealed that while models trained on all 10 autofluorescence imaging 
endpoints yielded the highest accuracy for classification of activation state of $\mathrm{T}$ cells, logistic regression using only $\mathrm{NAD}(\mathrm{P}) \mathrm{H} \alpha_{1}$ yielded comparably high ROC AUCs and was more accurate for predicting $\mathrm{T}$ cell activation than cell size alone (Fig. 2E), or fluorescence intensity measurements (cell size + redox ratio), which can be obtained by wide-field or confocal fluorescence microscopy. Additional label-free methods, including third harmonic generation imaging and Raman spectroscopy of quiescent and activated splenicderived murine $\mathrm{T}$ cells have revealed a significant increase in cell size and lipid content in activated $\mathrm{T}$ cells [42]. However, we observed a high variance in cell size within and across patients, which makes it a less important predictor than $\mathrm{NAD}(\mathrm{P}) \mathrm{H}$ lifetime values that change with activation and have lower variance (Fig. S10).

$\mathrm{CD}^{+}{ }^{\mathrm{CD}} 4^{+} \mathrm{T}$ cells have a variety of immune-modulating behaviors. While not necessary for activation of $\mathrm{CD} 3{ }^{+} \mathrm{CD} 8{ }^{+} \mathrm{T}$ cells, the presence of $\mathrm{CD} 3{ }^{+} \mathrm{CD} 4{ }^{+} \mathrm{T}$ cells during activation is required for the development of memory $\mathrm{CD}^{+}{ }^{+} \mathrm{CD} 8^{+} \mathrm{T}$ cells [43]. Additionally, $\mathrm{T}_{R E G S}\left(\mathrm{CD} 3^{+} \mathrm{CD} 4^{+} \mathrm{FoxP}^{+} \mathrm{T}\right.$ cells, $5-10 \%$ of peripheral $\mathrm{CD} 3{ }^{+} \mathrm{CD} 4^{+}$population) suppress the activation and proliferation of other T cells [44, 45]. Differences in the $\mathrm{NAD}(\mathrm{P}) \mathrm{H}$ and FAD autofluorescence imaging endpoints (Fig. 4, S15) between $\mathrm{CD} 3^{+} \mathrm{CD} 8^{+} \mathrm{T}$ cells cultured with and without $\mathrm{CD}^{+}{ }^{+} \mathrm{CD} 4^{+} \mathrm{T}$ cells were observed, suggesting autofluorescence imaging is sensitive to $\mathrm{CD}^{+}{ }^{+} \mathrm{CD} 4{ }^{+}$induced changes in $\mathrm{CD} 3{ }^{+} \mathrm{CD} 8{ }^{+} \mathrm{T}$ cells (Fig. 4). However, despite these differences, NAD(P)H $\alpha_{1}$ remains the highest weighted feature for classification of activation state (Fig. S16), and activation state of $\mathrm{CD} 3^{+} \mathrm{CD} 8^{+} \mathrm{T}$ cells can be classified from autofluorescence imaging endpoints with high accuracy, regardless of $\mathrm{T}$ cell population (Fig. 4D).

Due to the differing physiological functions of $\mathrm{CD} 3{ }^{+} \mathrm{CD} 4^{+}$and $\mathrm{CD} 3^{+} \mathrm{CD} 8^{+} \mathrm{T}$ cells $[1,46]$, it is important to detect $\mathrm{CD}^{+}{ }^{+} \mathrm{CD} 4^{+}$and $\mathrm{CD}^{+}{ }^{+} \mathrm{CD} 8^{+}$subtypes of $\mathrm{T}$ cells in addition to the activation state of $\mathrm{T}$ cells. Therefore, we explored whether machine learning methods could use autofluorescence imaging data to distinguish between $\mathrm{CD} 3^{+} \mathrm{CD} 8^{+}$and $\mathrm{CD} 3^{+} \mathrm{CD} 4^{+} \mathrm{T}$ cells within bulk $\mathrm{CD} 3^{+}$populations. Significant differences in $\mathrm{NAD}(\mathrm{P}) \mathrm{H}$ fluorescence lifetime values between $\mathrm{CD} 3{ }^{+} \mathrm{CD} 4{ }^{+}$and $\mathrm{CD} 3{ }^{+} \mathrm{CD} 8^{+} \mathrm{T}$ cells suggests variations in metabolic activity upon activation of $\mathrm{CD} 3^{+} \mathrm{CD} 4^{+}$and $\mathrm{CD} 3^{+} \mathrm{CD} 8^{+} \mathrm{T}$ cells, which is consistent with previously observed differences in $\mathrm{CD}^{+} \mathrm{CD} 4^{+}$and $\mathrm{CD} 3^{+} \mathrm{CD} 8^{+} \mathrm{T}$ cell activation: $\mathrm{CD} 3^{+} \mathrm{CD} 4^{+}$ activation occurs through $\mathrm{Myc}, \mathrm{ERR} \alpha$, and $\mathrm{mTOR}$, while $\mathrm{CD} 3^{+} \mathrm{CD} 8^{+} \mathrm{T}$ cells activate through Akt and mTOR [47]. These subtle differences in metabolic pathway utilization by $\mathrm{CD} 3^{+} \mathrm{CD} 4^{+}$and $\mathrm{CD} 3^{+} \mathrm{CD} 8^{+} \mathrm{T}$ cells enabled high classification accuracy of not only quiescent $\mathrm{CD} 3^{+} \mathrm{CD} 4^{+}$from quiescent $\mathrm{CD} 3^{+} \mathrm{CD} 8^{+}$cells and activated $\mathrm{CD} 3{ }^{+} \mathrm{CD} 4^{+}$from activated $\mathrm{CD} 3^{+} \mathrm{CD} 8^{+}$cells, but also all four groups, activated and quiescent $\mathrm{CD}^{+}{ }^{+} \mathrm{CD} 4^{+}$from activated and quiescent $\mathrm{CD} 3^{+} \mathrm{CD} 8^{+}$accurately (Fig. 4H). Although successful classification was achieved for $\mathrm{CD}^{+} \mathrm{CD} 4^{+}$versus $\mathrm{CD} 3^{+} \mathrm{CD} 8^{+} \mathrm{T}$ cells, these changes are much subtler than the metabolic changes with activation, as evidenced by the increased number of cells needed to train the models 
to achieve high classification accuracy (Fig. 4D,H).

Autofluorescence lifetime imaging has spatial and temporal resolution advantages over traditional assays to survey $\mathrm{T}$ cell activation and function. Autofluorescence imaging can be high resolution to allow measurements at the single cell level, allowing insights into metabolic heterogeneity within $\mathrm{T}$ cell populations. Additionally, the high spatial resolution and non-destructive nature of autofluorescence imaging maintains the spatial integrity of immune cells, allowing high fidelity measurements on neighboring cells as demonstrated in the combined population of quiescent and activated $\mathrm{T}$ cells (Fig. 5A). Finally, autofluorescence imaging also has high temporal resolution (Fig. 5F) allowing time-course study of $\mathrm{T}$ cell activation. Altogether, autofluorescence lifetime imaging of $\mathrm{NAD}(\mathrm{P}) \mathrm{H}$ and $\mathrm{FAD}$ of $\mathrm{T}$ cells, combined with machine learning for classification, is a powerful tool for non-destructive, label-free assessment of activation status of $\mathrm{T}$ cells. $\mathrm{NAD}(\mathrm{P}) \mathrm{H}$ and FAD autofluorescence lifetime imaging is label-free and provides high spatial, temporal, and functional information of cell metabolism, which makes it an attractive tool to evaluate $\mathrm{T}$ cells in vivo or characterize expanded $\mathrm{T}$ cells.

\section{Methods}

\subsection{T cell Isolation and Culture}

This study was approved by the Institutional Review Board of the University of Wisconsin-Madison (\#20180103), and informed consent was obtained from all donors. Peripheral blood was drawn from 6 healthy donors into sterile syringes containing heparin. Two blood draws, 183 days apart, were performed on one donor to evaluate the consistency of the experimental protocol and imaging endpoints. Bulk $\mathrm{CD}^{+} \mathrm{T}$ cells or an isolated $\mathrm{CD}^{+} \mathrm{CD} 8^{+} \mathrm{T}$ cell subset were extracted from whole blood using negative selection methods (RosetteSep, StemCell Technologies) and cultured in ImmunoCult-XF T cell Expansion Medium (StemCell Technologies). Approximately 24 hours post-isolation, the T cells were divided into two groups, a "quiescent" population that was grown in medium without activating antibodies, and an "activated" population that was cultured in medium supplemented with $25 \mathrm{\mu l} / \mathrm{ml}$ tetrameric antibody against CD2/CD3/CD28 (StemCell Technologies). Quiescent and activated $\mathrm{T}$ cell populations were cultured separately for 48 hours at $37^{\circ} \mathrm{C}$, $5 \% \mathrm{CO}_{2}$, and $99 \%$ humidity before imaging and subsequent experiments, unless otherwise noted. Prior to imaging, T cells were plated at approximately 200,000 cells/200 $\mu \mathrm{l}$ media on $35 \mathrm{~mm}$ poly-d-lysine coated glass bottom dishes (MatTek). To ensure that autofluorescence imaging and the classification models extend for mixed populations of quiescent and activated $\mathrm{T}$ cells, a subset of quiescent and activated $\mathrm{T}$ cells (48hr of culture with activating antibody) were combined and plated together in a dish 1 hour before imaging. 


\subsection{Autofluorescence Imaging of $\mathrm{NAD}(\mathrm{P}) \mathrm{H}$ and FAD}

Fluorescence images were acquired using an Ultima (Bruker Fluorescence Microscopy) two-photon microscope coupled to an inverted microscope body (TiE, Nikon) with an Insight DS+ (Spectra Physics) as the excitation source. A 100X objective (Nikon Plan Apo Lambda, NA 1.3), lending an approximate field of view of 110 um, was used in all experiments with the laser tuned to $750 \mathrm{~nm}$ for $\mathrm{NAD}(\mathrm{P}) \mathrm{H}$ two-photon excitation and $890 \mathrm{~nm}$ for FAD two-photon excitation. NAD(P)H and FAD images were acquired sequentially through 440/80 nm and 500/100 nm bandpass filters (Chroma), respectively, by GaAsP photomultiplier tubes (PMTs; H7422, Hamamatsu). The laser power at the sample was 3.0-3.2 $\mathrm{mW}$ for $\mathrm{NAD}(\mathrm{P}) \mathrm{H}$ and 4.1-4.3 $\mathrm{mW}$ for FAD. Lifetime imaging was performed within Prairie View (Bruker Fluorescence Microscopy) using time-correlated single photon counting electronics (SPC-150, Becker \& Hickl, Berlin, Germany). Fluorescence lifetime decays with 256 time bins were acquired across 256x256 pixel images with a pixel dwell time of 4.6 us and an integration time of $60 \mathrm{~s}$. Photon count rates were ${ }^{\sim} 1-5 \times 10^{5}$ and monitored during image acquisition to ensure that no photobleaching occurred. The second harmonic generation at $890 \mathrm{~nm}$ from red blood cells was used as the instrument response function and had a full width at half maximum of $240 \mathrm{ps}$. A YG fluorescent bead $(\tau=$ $2.13+/-0.03 \mathrm{~ns}, \mathrm{n}=6)$ was imaged daily as a fluorescence lifetime standard [14, 18, 48]. Four to six images per group were acquired.

\subsection{Antibody Validation}

Antibodies against CD4 (clone OKT4, PerCP-conjugated, Biolegend Item \#317431, Lot B198303), CD8 (clone SK1, PerCP-conjugated, Biolegend Item \#344707, Lot B204988), CD69 (clone FN50, PerCPconjugated, Biolegend Item \#310927, Lot B180058), CD45RA (clone HI100, Alexa 647-conjugated, Biolegend Item \#304153, Lot B220325), and CD45RO (clone UCHL1, PerCP-conjugated, Biolegend Item \#304251, Lot B219295) were used for validation of cell type and activation. Cells (30,000-200,000 per condition) were stained with $5 \mu \mathrm{l}$ antibody $/ 10^{6}$ cells in $50 \mathrm{\mu l}$ of ImmunoCult-XF T cell Expansion Medium for 30 minutes in the dark at room temperature. Cells were washed with ImmunoCult 1-2 times, resuspended in 50-200 $\mu \mathrm{l}$ of media, and added to the center of a $35 \mathrm{~mm}$ poly-d-lysine coated glass bottom dish (MatTek). Cells were kept in a $37^{\circ} \mathrm{C}, 5 \% \mathrm{CO}_{2}$, humidified environment until imaging. All cells were imaged within 3 hours of staining. $\mathrm{NAD}(\mathrm{P}) \mathrm{H}$ and $\mathrm{FAD}$ fluorescence lifetime images were acquired as described. To identify PerCP positive cells, an additional fluorescence intensity image was acquired with the Titanium:Sapphire laser tuned to $1040 \mathrm{~nm}$ and a 690/45 nm bandpass filter before the PMT. For evaluation of Alexa647 fluorescence, the Titanium:Sapphire laser was tuned to $1300 \mathrm{~nm}$ for excitation, and a 690/45 nm bandpass filter was used to filter emitted light. 


\subsection{Data Analysis}

Fluorescence lifetime decays were analyzed to extract fluorescence lifetime components (SPCImage, Becker \& Hickl). A bin of 9 surrounding pixels (3x3) was used to increase the fluorescence counts in each decay. A threshold was used to exclude pixels with low fluorescence signal (i.e. background). Fluorescence lifetime decays were deconvolved from the instrument response function and fit to a 2 component exponential decay model, $\mathrm{I}(\mathrm{t})=\alpha_{1} e^{-t / \tau_{1}}+\alpha_{2} e^{-t / \tau_{2}}+\mathrm{C}$, where $\mathrm{I}(\mathrm{t})$ is the fluorescence intensity as a function of time, $\mathrm{t}$, after the laser pulse, $\alpha_{1}$ and $\alpha_{2}$ are the fractional contributions of the short and long lifetime components, respectively (i.e., $\alpha_{1}+\alpha_{2}=1$ ), $\tau_{1}$ and $\tau_{2}$ are the short and long lifetime components, respectively, and $\mathrm{C}$ accounts for background light. Both $\mathrm{NAD}(\mathrm{P}) \mathrm{H}$ and FAD can exist in quenched (short lifetime) and unquenched (long lifetime) configurations $[9,13]$; therefore, the fluorescence decays of NAD $(\mathrm{P}) \mathrm{H}$ and FAD are fit to two components.

Images were analyzed at the single cell level to evaluate cellular heterogeneity [49]. NAD $(\mathrm{P}) \mathrm{H}$ intensity images were segmented into cytoplasm and nucleus using edge detect and thresholding methods in CellProfiler using a customized image processing routine [50]. Images of the optical redox ratio (fluorescence intensity of $\mathrm{NAD}(\mathrm{P}) \mathrm{H}$ divided by the summed intensity of $\mathrm{NAD}(\mathrm{P}) \mathrm{H}$ and FAD) and mean fluorescence lifetimes $\left(\tau_{m}\right.$ $\left.=\alpha_{1} \tau_{1}+\alpha_{2} \tau_{2}\right)$ of $\mathrm{NAD}(\mathrm{P}) \mathrm{H}$ and FAD were computed (MATLAB). NAD(P)H and FAD autofluorescence imaging endpoints, including the optical redox ratio, $\mathrm{NAD}(\mathrm{P}) \mathrm{H} \tau_{m}, \mathrm{NAD}(\mathrm{P}) \mathrm{H} \tau_{1}, \mathrm{NAD}(\mathrm{P}) \mathrm{H} \tau_{2}, \mathrm{NAD}(\mathrm{P}) \mathrm{H}$ $\alpha_{1}, \operatorname{FAD} \tau_{m}, \operatorname{FAD} \tau_{1}, \operatorname{FAD} \tau_{2}$, and FAD $\alpha_{1}$ were averaged across all pixels within a cell cytoplasm for each segmented cell. Cell size in $\mu^{2}$ was also computed from the segmented images using the number of pixels within the $2 \mathrm{D}$-image of the cell $* 0.167 \mu^{2}$ (which is the pixel dimension).

Statistical analysis and data representation were performed in R. A generalized linear model was used to evaluate significant differences $(\alpha=0.05)$ of autofluorescence imaging endpoints between quiescent and activated $\mathrm{T}$ cells, CD45RA ${ }^{+}$and $\mathrm{CD}_{4}$ RO ${ }^{+}$cells (Fig. 3), and $\mathrm{CD}^{+}{ }^{+} \mathrm{CD} 4^{+}$and $\mathrm{CD}^{+} \mathrm{CD} 8^{+} \mathrm{T}$ cells. Presented boxplots are constructed from the median (central line) and first and third quartiles (lower and upper hinges, respectively). The whiskers extend to the farthest data points that are no further than $1.5^{*}$ the interquartile range. Dots represent data points beyond $1.5^{*}$ the interquartile range from the hinge.

\subsection{Classification}

Uniform Manifold Approximate and Projection (UMAP), a dimension reduction technique [26], and z-score heatmaps were used to visualize clustering within autofluorescence imaging data sets (Python and R, respectively). Machine learning classification models and training/testing data sets are summarized in Table S1. Random forest, logistic regression, and support vector machine classification methods were trained to 
classify activated and quiescent $\mathrm{T}$ cells within either the bulk CD3 ${ }^{+}$FLIM data or the isolated $\mathrm{CD} 3^{+} \mathrm{CD} 8^{+}$ FLIM data (R). For both data sets, gain ratio, $\chi^{2}$, and random forest feature selection methods were employed to evaluate the contribution of the $\mathrm{NAD}(\mathrm{P}) \mathrm{H}$ and FAD autofluorescence endpoints to the accuracy of classification of quiescent versus activated T cells. These models were trained on data from donors A, B, $\mathrm{C}$, and D because these cells lacked immunofluorescence CD69 validation but were known to be quiescent or activated by culture conditions $\left(\mathrm{n}=4131 \mathrm{CD} 3^{+}\right.$cells, $\mathrm{n}=2655 \mathrm{CD} 3^{+} \mathrm{CD} 8^{+}$cells $)$. Models were tested on data from $\mathrm{T}$ cells from donors $\mathrm{B}, \mathrm{E}$, and $\mathrm{F}$ with CD69 immunofluorescence validation of activation state ( $\mathrm{n}$ $=696 \mathrm{CD}^{+}$cells, $\mathrm{n}=595 \mathrm{CD}^{+} \mathrm{CD} 8^{+}$cells). Random forest models were developed to classify CD3 ${ }^{+} \mathrm{CD} 4^{+}$ from $\mathrm{CD} 3^{+} \mathrm{CD} 8^{+} \mathrm{T}$ cells, and cells were randomly assigned to training and test data sets for a range of train/test proportions from $12.5 \%$ to $87.5 \%$. Each model was replicated 50 times with new training and test data generated before each iteration. Logistic regression models were also estimated for the classification of $\mathrm{T}$ cell activation from imaging endpoints of combined quiescent and activated CD3 ${ }^{+} \mathrm{T}$ cells (both conditions together within the images). Observations were randomly divided into training and testing data sets (90\%/10\%, respectively), and presented ROC curves are the average of 1000 iterations of randomly selected training and testing data.

\subsection{Seahorse Assay}

Quiescent and activated $\mathrm{T}$ cells were plated at $5 \times 10^{6}$ cells $/ \mathrm{ml}$ on a Seahorse 96 -well plate in unbuffered RPMI medium without serum. Oxygen consumption rate (OCR) and extracellular acidification rate (ECAR) measurements were obtained every 6.5 minutes for 5 cycles. A generalized linear model was used to determine statistical significance $(\alpha=0.05)$ within OCR and ECAR measurements between control and activated T cells.

\subsection{Metabolic Inhibitors}

Quiescent and activated $(48 \mathrm{hr}) \mathrm{CD}^{+} \mathrm{T}$ cells were plated on poly-d-lysine coated $35 \mathrm{~mm}$ glass bottom dishes at a concentration of $\sim 200,000$ cells/200 $\mu$ lmmunoCult T cell Expansion Medium as previously described ( $\mathrm{T}$ cell Isolation and Culture). The metabolic inhibitors antimycin $\mathrm{A}(1 \mu \mathrm{M})$, rotenone $(1 \mu \mathrm{M})$, 2-deoxy-d-glucose (2DG, $50 \mathrm{mM}$ ), Bis-2-(5-phenylacetamido-1,3,4-thiadiazol-2-yl)ethyl sulfide (BPTES, 20 $\mu \mathrm{M}$ ), and 5-(Tetradecyloxy)-2-furoic acid (TOFA, $501 \mathrm{\mu g} / \mathrm{ml}$ ) were added singly, except for antimycin A and rotenone which were added together, to the dishes prior to imaging. Cells were incubated with antimycin A and rotenone for ten minutes, 2DG for ten minutes, BPTES for 1 hour, and TOFA for 1 hour. Fluorescence lifetime images of $\mathrm{NAD}(\mathrm{P}) \mathrm{H}$ and FAD were acquired for 6 random fields of view as described 
above. A generalized linear model was used to determine autofluorescence imaging endpoints with statistical significance $(\alpha=0.05)$ between control and inhibitor-exposed cells.

\subsection{Activation Time Course}

Quiescent $\mathrm{CD}^{+} \mathrm{T}$ cells were isolated and plated for imaging as previously described. NAD(P)H lifetime images were acquired as described but with an image size of 128x128 pixels and an integration time of 15 s. Images were acquired sequentially for 2 minutes ( 8 frames), then $5 \mu$ PBS was added to the cells as a mock treatment, and $\mathrm{NAD}(\mathrm{P}) \mathrm{H}$ fluorescence lifetime images were acquired for 10 minutes (40 frames). Subsequently, $5 \mu \mathrm{l}$ of activating tetrameric antibody (anti-CD2/CD3/CD28) was added and NAD(P)H fluorescence lifetime images were acquired for 10 minutes (40 frames). NAD(P)H FLIM images were analyzed in SPCImage as described. Individual cells and cell compartments (nucleus, cytoplasm) were manually segmented (author I.J.), and the autofluorescence imaging endpoints were averaged across all pixels within the segmented region (ImageJ). This procedure was repeated for 3 dishes for a total of 34 analyzed cells.

\subsection{Data Availability}

The datasets generated during and/or analyzed during the current study are available from the corresponding authors on reasonable request.

\subsection{Code Availability}

All code and algorithms generated during the current study are available from the corresponding authors on reasonable request.

\section{References}

1. Mosmann, T. R. \& Coffman, R. L. in Advances in Immunology Volume 46 111-147 (Elsevier, 1989).

2. Bettelli, E., Korn, T. \& Kuchroo, V. K. Th17: the third member of the effector T cell trilogy. Current Opinion in Immunology 19, 652-657 (Dec. 2007).

3. Pardoll, D. M. The blockade of immune checkpoints in cancer immunotherapy. Nature Reviews Cancer 12, 252-264 (Apr. 2012).

4. Restifo, N. P., Dudley, M. E. \& Rosenberg, S. A. Adoptive immunotherapy for cancer: harnessing the T cell response. Nature Reviews Immunology 12, 269-281 (Apr. 2012). 
5. Canavan, J. B. et al. Developing in vitro expanded CD45RA+regulatory T cells as an adoptive cell therapy for Crohn's disease. Gut 65, 584-594 (Feb. 2015).

6. Marek-Trzonkowska, N. et al. Administration of CD4+CD25highCD127- Regulatory T Cells Preserves -Cell Function in Type 1 Diabetes in Children. Diabetes Care 35, 1817-1820 (June 2012).

7. Todo, S. et al. A pilot study of operational tolerance with a regulatory T-cell-based cell therapy in living donor liver transplantation. Hepatology 64, 632-643 (Mar. 2016).

8. Chance, B., Schoener, B., Oshino, R., Itshak, F. \& Nakase, Y. Oxidation-reduction ratio studies of mitochondria in freeze-trapped samples. NADH and flavoprotein fluorescence signals. Journal of Biological Chemistry 254, 4764-4771 (1979).

9. Lakowicz, J. R., Szmacinski, H., Nowaczyk, K. \& Johnson, M. L. Fluorescence lifetime imaging of free and protein-bound NADH. Proceedings of the National Academy of Sciences 89, 1271-1275 (Feb. 1992).

10. Georgakoudi, I. \& Quinn, K. P. Optical imaging using endogenous contrast to assess metabolic state. Annual review of biomedical engineering 14, 351-367 (2012).

11. Huang, S., Heikal, A. A. \& Webb, W. W. Two-Photon Fluorescence Spectroscopy and Microscopy of NAD(P)H and Flavoprotein. Biophysical Journal 82, 2811-2825 (May 2002).

12. Varone, A. et al. Endogenous Two-Photon Fluorescence Imaging Elucidates Metabolic Changes Related to Enhanced Glycolysis and Glutamine Consumption in Precancerous Epithelial Tissues. Cancer Research 74, 3067-3075 (Mar. 2014).

13. Nakashima, N., Yoshihara, K., Tanaka, F. \& Yagi, K. Picosecond fluorescence lifetime of the coenzyme of D-amino acid oxidase. Journal of Biological Chemistry 255, 5261-5263 (1980).

14. Skala, M. C. et al. In vivo multiphoton microscopy of NADH and FAD redox states, fluorescence lifetimes, and cellular morphology in precancerous epithelia. Proceedings of the National Academy of Sciences 104, 19494-19499 (Nov. 2007).

15. Quinn, K. P. et al. Quantitative metabolic imaging using endogenous fluorescence to detect stem cell differentiation. Scientific Reports 3 (Dec. 2013).

16. Walsh, A. J. et al. Quantitative Optical Imaging of Primary Tumor Organoid Metabolism Predicts Drug Response in Breast Cancer. Cancer Research 74, 5184-5194 (Aug. 2014).

17. Walsh, A. J., Castellanos, J. A., Nagathihalli, N. S., Merchant, N. B. \& Skala, M. C. Optical Imaging of Drug-Induced Metabolism Changes in Murine and Human Pancreatic Cancer Organoids Reveals Heterogeneous Drug Response. Pancreas 45, 863-869 (July 2016). 
18. Walsh, A. J. et al. Optical Metabolic Imaging Identifies Glycolytic Levels, Subtypes, and Early Treatment Response in Breast Cancer. Cancer Research 73, 6164-6174 (Oct. 2013).

19. Stringari, C. et al. Phasor approach to fluorescence lifetime microscopy distinguishes different metabolic states of germ cells in a live tissue. Proceedings of the National Academy of Sciences 108, 13582-13587 (Aug. 2011).

20. Alfonso-García, A. et al. Label-free identification of macrophage phenotype by fluorescence lifetime imaging microscopy. Journal of Biomedical Optics 21, 046005 (Apr. 2016).

21. Szulczewski, J. M. et al. In Vivo Visualization of Stromal Macrophages via label-free FLIM-based metabolite imaging. Scientific Reports 6 (May 2016).

22. Pavillon, N., Hobro, A. J., Akira, S. \& Smith, N. I. Noninvasive detection of macrophage activation with single-cell resolution through machine learning. Proceedings of the National Academy of Sciences 115, E2676-E2685 (Mar. 2018).

23. Frauwirth, K. A. et al. The CD28 Signaling Pathway Regulates Glucose Metabolism. Immunity 16, 769-777 (June 2002).

24. Chang, C.-H. et al. Posttranscriptional Control of T Cell Effector Function by Aerobic Glycolysis. Cell 153, 1239-1251 (June 2013).

25. Michalek, R. D. et al. Cutting Edge: Distinct Glycolytic and Lipid Oxidative Metabolic Programs Are Essential for Effector and Regulatory CD4+ T Cell Subsets. The Journal of Immunology 186, 32993303 (Feb. 2011).

26. McInnes, L. \& Healy, J. UMAP: Uniform Manifold Approximation and Projection for Dimension Reduction. arXiv: http://arxiv.org/abs/1802.03426v1 (Feb. 9, 2018).

27. Van der Windt, G. J. W. et al. CD8 memory T cells have a bioenergetic advantage that underlies their rapid recall ability. Proceedings of the National Academy of Sciences 110, 14336-14341 (Aug. 2013).

28. Zhang, Q., Piston, D. W. \& Goodman, R. H. Regulation of Corepressor Function by Nuclear NADH. Science 295, 1895-1897. ISSN: 0036-8075 (2002).

29. Wang, R. et al. The Transcription Factor Myc Controls Metabolic Reprogramming upon T Lymphocyte Activation. Immunity 35, 871-882 (Dec. 2011).

30. Wang, R. \& Green, D. R. Metabolic checkpoints in activated T cells. Nature Immunology 13, 907-915 (Sept. 2012).

31. Kishton, R. J., Sukumar, M. \& Restifo, N. P. Metabolic Regulation of T Cell Longevity and Function in Tumor Immunotherapy. Cell Metabolism 26, 94-109 (July 2017). 
32. Sharick, J. T. et al. Protein-bound NAD(P)H Lifetime is Sensitive to Multiple Fates of Glucose Carbon. Scientific Reports 8 (Apr. 2018).

33. Liu, Z. et al. Mapping metabolic changes by noninvasive, multiparametric, high-resolution imaging using endogenous contrast. Science Advances 4. doi:10.1126/sciadv.aap9302 (Mar. 2018).

34. Chang, J. T., Wherry, E. J. \& Goldrath, A. W. Molecular regulation of effector and memory T cell differentiation. Nature Immunology 15, 1104-1115 (Dec. 2014).

35. Kaech, S. M. \& Cui, W. Transcriptional control of effector and memory CD8+ T cell differentiation. Nature Reviews Immunology 12, 749-761 (Oct. 2012).

36. Palmer, M. J., Mahajan, V. S., Chen, J., Irvine, D. J. \& Lauffenburger, D. A. Signaling thresholds govern heterogeneity in IL-7-receptor-mediated responses of naïve CD8+ T cells. Immunology and Cell Biology 89, 581-594 (Feb. 2011).

37. Tubo, N. J. et al. Single Naive CD4+ T Cells from a Diverse Repertoire Produce Different Effector Cell Types during Infection. Cell 153, 785-796 (May 2013).

38. Krylov, S. N. et al. Correlating cell cycle with metabolism in single cells: Combination of image and metabolic cytometry. Cytometry 37, 14-20 (Sept. 1999).

39. Heaster, T. M., Walsh, A. J., Zhao, Y., Hiebert, S. W. \& Skala, M. C. Autofluorescence imaging identifies tumor cell-cycle status on a single-cell level. Journal of Biophotonics 11, e201600276 (May 2017).

40. Chen, C. L. et al. Deep Learning in Label-free Cell Classification. Scientific Reports 6 (Mar. 2016).

41. Blasi, T. et al. Label-free cell cycle analysis for high-throughput imaging flow cytometry. Nature Communications 7, 10256 (Jan. 2016).

42. Gavgiotaki, E. et al. Detection of the T cell activation state using non-linear optical microscopy. Journal of Biophotonics, e201800277 (Oct. 2018).

43. Janssen, E. M. et al. CD4+ T cells are required for secondary expansion and memory in CD8+ T lymphocytes. Nature 421, 852-856 (Feb. 2003).

44. Takahashi, T. et al. Immunologic Self-Tolerance Maintained by Cd25+Cd4+Regulatory T Cells Constitutively Expressing Cytotoxic T Lymphocyte-Associated Antigen 4. The Journal of Experimental Medicine 192, 303-310 (July 2000).

45. Dieckmann, D., Plottner, H., Berchtold, S., Berger, T. \& Schuler, G. Ex Vivo Isolation and Characterization of $\mathrm{Cd} 4+\mathrm{Cd} 25+\mathrm{T}$ Cells with Regulatory Properties from Human Blood. The Journal of Experimental Medicine 193, 1303-1310 (June 2001). 
46. Naito, Y. et al. CD8+ T Cells Infiltrated within Cancer Cell Nests as a Prognostic Factor in Human Colorectal Cancer. Cancer Research 58, 3491-3494 (1998).

47. Gerriets, V. A. \& Rathmell, J. C. Metabolic pathways in T cell fate and function. Trends in Immunology 33, 168-173 (Apr. 2012).

48. Bird, D. K. et al. Metabolic Mapping of MCF10A Human Breast Cells via Multiphoton Fluorescence Lifetime Imaging of the Coenzyme NADH. Cancer Research 65, 8766-8773 (Oct. 2005).

49. Walsh, A. J. \& Skala, M. C. Optical metabolic imaging quantifies heterogeneous cell populations. Biomedical Optics Express 6, 559 (Jan. 2015).

50. Walsh, A. J. \& Skala, M. C. An automated image processing routine for segmentation of cell cytoplasms in high-resolution autofluorescence images in Multiphoton Microscopy in the Biomedical Sciences XIV (SPIE, Feb. 2014).

\section{Acknowledgments}

The authors would like to thank Arezoo Movaghar for insightful discussions of feature selection and machine learning classification methods and Rebecca Schmitz for her assistance with formatting of paper figures. This work was funded by the NIH NCI R01 CA205101 (to M.C.S); the Biotechnology Training Program of the National Institute of General Medical Sciences of the National Institutes of Health, award \#T32GM008349 (to K.S.); NIH awards R01DK098672 and P41GM108538 (to D.J.P.) and T32DK007665 (to N.M.N.); the NSF Graduate Research Fellowship Program, DGE-1747503 (to K.M); and the National Science Foundation under Grant No. EEC-1648035 (to K.S.).

\section{Author Contributions}

AW and MS conceived the central hypotheses, and KM contributed the hypothesis on distinguishing $\mathrm{CD} 3{ }^{+} \mathrm{CD} 8{ }^{+}$naïve versus memory $\mathrm{T}$ cell autofluorescence properties. KM and AW designed and performed the experiments with assistance from NP. AW and IJ analyzed the data. NN and KM performed the Seahorse assay. CW provided statistical insight and data analysis code. KS and MS supervised the project. AW wrote the initial draft of the manuscript. All authors contributed to data interpretation and the final manuscript. 
bioRxiv preprint doi: https://doi org/10.1101/536813. this version posted January 31 2019. The copyright holder for this preprint (which was not certified by peer review) is the author/funder, who has granted bioRxiv a license to display the preprint in perpetuity. It is made available under aCC-BY-NC-ND 4.0 International license.

\section{${ }_{610} \quad 7 \quad$ Competing Interests}

${ }_{611}$ A patent application has been filed on this work.

\section{${ }_{612} 8$ Correspondence}

${ }_{613}$ Correspondence to Alex J. Walsh or Melissa C. Skala. 